\title{
Do Institutional Investors Influence Capital Structure Decisions?
}

\author{
Roni Michaely and Christopher Vincent*
}

January 2013

\begin{abstract}
This paper empirically investigates the relationship between institutional holdings and capital structure. Institutions may affect capital structure through their monitoring and information-gathering roles. At the same time, institutions may gravitate toward firms with specific capital structures, forming leverage-based investment clienteles. Using implied trades generated from mutual fund outflows as an instrument for institutional holdings, and a semi-natural experiment in which addition to the S\&P 500 Index provides an exogenous shock to institutional holdings, we find that institutional holdings are a significant determinant of firms' capital structures: A change in institutional holdings causes an opposite change in leverage. Moreover, using dynamic panel estimation, we find that while institutions affect capital structure decisions, changes in leverage do not affect institutional holdings, and there is no evidence of a clientele effect. Finally, we find that firms lower their leverage in response to increased institutional holdings by becoming more likely to issue equity, and less likely to increase debt. While our findings are consistent with models in which institutions substitute for debt by monitoring and reducing information asymmetry problems, further evidence suggests that the effect on asymmetric information dominates.
\end{abstract}

* Roni Michaely is from the Johnson School of Management, Cornell University and the IDC. Christopher Vincent is from the Johnson School of Management, Cornell University. Emails: Roni Michaely rm34@cornell.edu; Christopher Vincent cjv34@cornell.edu. We greatly appreciate the comments of Jacob Boudoukh, David De Angelis, Mark Flannery, Itay Goldstein, Vidhan Goyal, Yaniv Grinstein, Ohad Kadan, Andrew Karolyi, Shimon Kogan, Yelena Larkin, Mark Leary, Kai Li, Michelle Lowry, Jillian Popadak, Gideon Saar, Denis Sosyura, Lukas Roth, Feng Zhang, and seminar participants at Cornell University, Georgetown University, Nanyang Technological University, National University of Singapore, Singapore Management University, University of Alberta, University of British Columbia, University of Michigan, University of Syracuse, University of Toronto, University of Utah, the Corporate Finance Conference at HKUST, the Corporate Finance Conference at the University of Washington at St. Louis, and the SEI summer conference at IDC. 
Institutions are arguably the most important and powerful class of investors. Their average equity ownership in U.S. firms has increased eight-fold over the past thirty years, and by the end of 2009 they held $70 \%$ of the aggregate U.S. market cap. ${ }^{1}$ For both large and small firms, institutions are now, more often than not, the majority investor group. In this paper we examine how institutional investors affect firms' capital structure, and how firms' financial leverage affects institutional investors' decisions to hold their equity.

Through the effects of institutional holdings on agency costs, asymmetric information, and taxes, institutions may affect the way in which firms structure their capital. As we elaborate in the next section, there are several reasons why this is likely to occur. First, by monitoring management through voice or (threat of) exit, institutions as equity holders reduce conflicts of interests between management and shareholders (e.g., Shleifer and Vishny (1986), Admati and Pfleiderer (2009), and Levit (2012)). Second, institutions gather information and make trades based on that information, and in doing so reduce information asymmetry problems associated with equity (e.g., Sias (2004), and Bushee and Goodman (2007)). Finally, as equity holders, institutions have, on average, a relative tax advantage over individual investors.

While institutional investors interact with the aforementioned frictions underlying many capital structure models, the resulting nature of the relationship between institutional holdings and capital structure is not clear. On one hand, institutional holdings and debt could be substitutes. If, for example, organizational inefficiencies must be controlled as in Jensen (1986), threatening to sell shares or unseat managers if they engage in "empire building" may be as effective as committing managers to pledge funds to creditors. Or, in the context of Myers and Majluf (1984), if institutional information-gathering and trading produces information (Sias (2004)), the adverse selection costs of equity may decline, leading firms to tilt toward a higher percentage of equity financing in their capital structures. In both cases, institutional holdings and debt would be substitutes.

On the other hand, institutional holdings and debt could act as complements. In an agency setting, it may be that by increasing investor protection institutional investors enable outside shareholders to implement devices such as debt that limit management discre-

${ }^{1}$ This figure is calculated using $13 \mathrm{~F}$ data as filed with the SEC, includes only publicly traded equity, and excludes ADR's and foreign incorporated firms. 
tion and better align the objectives of managers and shareholders (e.g. the "outcome model" in La Porta, Lopez-de-Silanes, Shleifer, and Vishny (2000)). Or in an informationasymmetry setting, it might be that institutions help solve future underinvestment problems caused by the adverse selection costs of equity (again, through their role as information producers), thus allowing firms to forgo issuing equity today (Viswanath (1993)). In either case, the relationship between institutional holdings and debt would be a complementary one.

While it is perhaps most natural to conjecture that managers take all information, including the extent of institutional equity holdings, into consideration before making capital structure decisions, institutions may also take firms' leverage into account when making their own investment decisions. As such, the effect may go in the opposite direction, and capital structure decisions may affect the level of institutional holdings in a firm. Recent work has shown institutional investors to form investment clienteles based on firm characteristics such as size and liquidity (Gompers and Metrick (2001)), payout policy (Grinstein and Michaely (2005)), and corporate governance (McCahery, Sautner, and Starks (2010)), which together suggest that institutions may also form capital structure investment clienteles.

Predicated on the testable implications of extant capital structure theories, we examine the interaction between institutional holdings and capital structure using annual data from the period 1979 to 2009 . Our first finding is a strong and robust negative relationship between institutional holdings and leverage: more institutional holdings in period $t$ are associated with less leverage in period $(t+1)$. The economic effect of institutional holdings on leverage is comparable in magnitude to known determinants of leverage such as profitability and industry median leverage, and the relationship holds after controlling for important factors that covary with institutional holdings, such as insider holdings and analyst coverage, as well as for known determinants of leverage, including initial firm leverage (Lemmon, Roberts, and Zender (2008)).

Although we make no prior claims regarding the direction of causality, we are interested in whether the effect of institutional holdings on leverage is of a causal nature. Hence, we employ three techniques to remove the potential feedback effect of leverage on holdings: two separate instrumental variables approaches and a semi-natural experiment. 
Our first technique is an Arellano-Bond dynamic panel estimation in which we instrument for changes in institutional holdings with lagged holdings.

Our second technique is a linear two-stage least squares estimation in which we use implied mutual fund trading induced by investor outflows as an instrument for institutional holdings (Edmans, Goldstein, and Jiang (2011)). Implied changes in mutual fund holdings affect aggregate institutional holdings, but not for reasons associated with firm characteristics such as leverage. That is, when a mutual fund experiences large outflows it must sell a portion of its holdings to repay investors. By using implied trades based on previously disclosed mutual fund holdings, we have an instrument that correlates with institutional holdings for mechanical reasons rather than informational reasons, and hence satisfies the exclusion restriction.

Our final technique looks at the change in leverage surrounding addition to the S\&P 500 Index. Standard \& Poor's explicitly aims to make index inclusion an information-free event, and as such we use it as treatment in two difference-in-differences estimations that test whether leverage changes differentially for treated firms - those added to the S\&P 500 - relative to a matched-sample of control firms - those that do not experience the shock to institutional holdings caused by index addition.

Even though the sample sizes vary dramatically across techniques, with all three approaches we find that leverage decreases in response to increases in institutional holdings. With the 2SLS estimation, we find that the decrease in leverage stemming from an increase in institutional holdings is about 2.8 times larger than what we find without instrumentation, and represents an $8.0 \%$ change in leverage per standard deviation change in holdings. Correspondingly, in our natural experiment, we show that after being added to the S\&P 500 Index, firms decrease their leverage by 1.5\% (7.7\% of the treatment group's average leverage) relative to a group of similar, propensity-score-matched control firms. Taken together, these results are consistent with a wide range of agency- and asymmetric information-based models of capital structure that predict a relationship advancing from agency costs or information asymmetry to leverage.

At the same time, we find the effect of capital structure on institutional holdings to be more ambiguous. In both level and first-difference regressions, we find that leverage has a negative effect on institutional holdings. However, in an Arellano-Bond estimation 
featuring (internal) instrumental variables, we find no effect of leverage on institutional holdings. In accordance with most capital structure theories, our findings point to a stronger effect advancing from institutional holdings to capital structure than from capital structure to institutional holdings.

Next, we investigate how firms change their capital structure in response to a change in institutional holdings. We find that an increase in institutional holdings significantly raises the subsequent probability of a firm being a net equity issuer, without affecting the probability of debt issuance. Furthermore, the size of equity issuances also increases with positive changes in institutional holdings. Consistent with direction of causality from institutions to leverage, and not the other way around, we do not find that an increase in equity issuances in year $t$ results in an increase in institutional holdings in year $(t+1)$. Together, these results suggest that equity issuances are the main channel through which firms adjust their capital structure in response to increased institutional holdings.

Although our results support both agency- and information-based models that imply institutional investors have a negative influence on firms' leverage, we find evidence that information asymmetry is the friction through which they most strongly impact capital structure. Firms particularly prone to high agency costs are, in general, large, profitable, cash-rich firms with relatively few growth opportunities. On the other hand, firms particularly prone to information asymmetry and high adverse selection costs are generally small, young, cash-strapped firms with relatively many growth opportunities. We find the effect of institutional holdings on leverage to be stronger in small firms with many growth opportunities ("asymmetric information firms") than in large firms with few growth opportunities ("agency firms), although in practice information asymmetry and agency costs are not mutually exclusive frictions.

Furthermore, we find no evidence that tax considerations play a role in the relationship between institutional holdings and leverage. We utilize the Jobs and Growth Tax Relief Reconciliation Act of 2003 (which lowers the relative tax advantage on equity by institutions) to test whether the relationship between institutional holdings and leverage changed. We find no difference in the effect of institutional holdings on leverage in the period before the tax change compared to the period after. 
Finally, we find the effect of institutional holdings on leverage to be quite robust. In addition to estimating the effect during various subperiods, we redefine leverage in a number of different ways - using a logit transformation, using only long term debt, using the market value of assets rather than the book value, using debt plus equity in the denominator rather than total assets, and by deducting excess cash from total debt - and our results hold regardless of the specification. In addition, we control for potential covariates such as market timing considerations, liquidity, and the corporate governance environment, and find that institutional holdings maintains its strong effect on firms' leverage. Lastly, we find our results to be robust to using quarterly data rather than annual data.

While prior literature has not focused on the relationship between capital structure and institutional investors, the idea that institutions may affect corporate financial policy has not been ignored. Specifically, recent work has shown institutional investors to play a role in mergers and acquisitions (Gaspar, Massa, and Matos (2005)), analyst activity and accuracy (Ljungqvist, Marston, Starks, Wei, and Yan (2007)), payout policy (Grinstein and Michaely (2005)), executive compensation (Hartzell and Starks (2003)), CEO turnover (Huson, Parrino, and Starks (2001)), and corporate governance (Gillan and Starks (2000)). Along these lines, Cronqvist and Fahlenbach (2009) find strong evidence of blockholder fixed effects in firms' investment and financial policies, as well as in firm performance measures. Our paper contributes to this literature.

The rest of the paper is organized as follows. In Section I we review the theoretical determinants for capital structure and discuss how institutional investors impact these determinants, and by extension, capital structure. In Section II we describe our data and construct several important variables. In Section III we test the relation between institutional holdings and leverage. In Section IV we conclude.

\section{Hypothesis development and related literature}

Many capital structure theories suggest that agency costs, asymmetric information, and taxes are important frictions that enable the choice of leverage to affect firm value. Institutional investors, however, often possess common characteristics that may impact the severity to which firms are affected by these frictions, thereby altering the process through which capital structure is determined. In this section, we briefly review several of the most 
relevant theories of capital structure, discuss some common institutional characteristics that suggest institutional investors interact with these frictions, and detail the implications of these interactions for firms' capital structures.

One set of capital structure models posits that the severity of conflicts of interests between managers and equity holders leads to a particular leverage ratio. Jensen and Meckling (1976) argue that this conflict is costly because it incentivizes managers to overindulge in activities beneficial only to them, as they bear the entire cost of refraining from these activities while reaping only a portion of the gains. Debt alleviates this inefficiency by increasing the manager's (relative) share of equity, thus increasing his ownership of the residual claim. In a similar vein, Jensen (1986) argues that debt mitigates shareholdermanager agency conflicts by committing managers to pledge funds to repay creditors, in turn lessening the amount of "free cash" available for organizational inefficiencies such as consuming perquisites and empire building.

Institutions, however, can affect the severity of firms' agency costs, because institutions engage in monitoring (e.g., Shleifer and Vishny (1986), Maug (1998), and Huson, Parrino, and Starks (2001)). In the presence of ineffective corporate control mechanisms (Jensen (1993)), "monitoring" activities are value-enhancing undertakings ranging from minimal intervention in a company's affairs to more aggressive techniques of shareholder activism, including the "Wall Street Walk," initiating pressure campaigns, and jockeying for a seat on the board of directors (e.g., Parrino, Sias, and Starks (2003), Gillan and Starks (2007), Admati and Pfleiderer (2009), and McCahery et al. (2010)). One strand of literature suggests that blockholders and investors with large holdings and long horizons are particularly effective monitors (Edmans (2009) and Chen, Harford, and Li (2007)), while another strand suggests that entire fund families vote in agreement due to centralized voting departments or ISS guidelines for proxy voting (e.g., Matvos and Ostrovsky (2010), Morgan, Poulsen, Wolf, and Yang (2011), and Iliev, Lins, Miller, and Roth (2012)). Thus, the implication is that all institutions, to some extent, can be effective monitors. For example, Fenn and Robinson (2009) find that even sponsors of indexed ETFs devote time and resources to monitoring firms' management, and are active by voting strategically in proxy contests. The goal of such activities is to reduce the conflicts of interest that exist between 
shareholders and managers, and in doing so, institutional investors can potentially influence capital structure decisions.

While many models suggest that shareholder-manager agency conflicts drive capital structure decisions (e.g., Stulz (1990), Zwiebel (1996), and Gomes (2000)), the manner in which institutions affect this relationship is not clear. The divergent theoretical implications are well illustrated in two models put forth by La Porta et al. (2000): the substitute model and the outcome model. In the context of the substitute model, institutional holdings provide investor protection while acting as an alternative bonding mechanism for debt, suggesting that, all else equal, firms with a high proportion of institutional holdings need less debt in equilibrium. On the other hand, in the outcome model outside investors must have adequate mechanisms in place, perhaps in the form of laws and regulations, before they can force management to increase debt and thereby limit potential wealth expropriation. Because institutional investors increase investor empowerment and protection, the outcome model implies that firms with a strong institutional shareholder base will have more debt.

A second set of capital structure models suggests that firms choose their capital structure in response to the information environment in which they operate. In these models, insiders (managers) possess information regarding their firm's future return stream or investment opportunities (i.e. their firm's intrinsic value) that is not known to outside investors. In general, debt is preferable to equity in firms with higher levels of information asymmetry mainly because it carries less adverse selection costs than equity.

Institutional investors can play an important role in asymmetric information models of capital structure because they devote considerable resources to collecting information. Many institutions are subject to state or federal fiduciary and prudency standards (see Del Guercio (1996)) incentivizing them to collect information about the firms they invest in in order to decrease the likelihood of being sued for violating these standards (Allen, Bernardo, and Welch (2000)). This process leads them to be more informed than other types of investors, but also affects the adverse selection costs of equity by decreasing the information gap between outside and inside shareholders, because at least a portion of the information they collect is reflected in their trading patterns (Sias (2004), and Bushee and Goodman (2007)). 
As with agency models, asymmetric information models of capital structure do not unilaterally imply the same relationship between institutional holdings and leverage. On one hand, the two can be inversely related. In Myers (1984) and Myers and Majluf (1984), due to information asymmetry and mispriced equity, firms may under-invest in positive NPV projects. As a result, firms fund investments by choosing financing sources that minimize adverse selection costs, preferring retained earnings over risky debt over equity (the pecking order). Institutional investors mitigate the adverse selection costs of equity, so as equity financing becomes comparatively cheaper, firms with high institutional holdings should have lower leverage than those with low institutional holdings. ${ }^{2}$

On the other hand, institutional holdings can have a positive effect on leverage in asymmetric information models of capital structure. Viswanath (1993) builds on the Myers and Majluf (1984) intuition that the dilutive costs of issuing equity may cause firms to reject worthwhile projects, and constructs a multi-period model in which firms optimally issue stock today, when information asymmetry is low, to avoid the potential loss of a positive NPV project in the future due to information asymmetry problems at that time. However, as institutions narrow the information gap between managers and (future) shareholders, they decrease the dilutive costs of future equity issuances. As such, a strong institutional shareholder base may allow firms to avoid issuing equity today, implying a complementary relationship between institutional holdings and leverage.

The tax status of institutional investors is a third characteristic that suggests institutions may affect capital structure. As equity holders, institutions generally have a relative tax advantage over individual investors. Many institutions are tax-exempt, while many others pay taxes on only a small portion of the dividends they receive from their investments. Thus, all else equal, a firm with a larger base of institutional equity holders should issue comparatively more equity than a firm owned by (higher-tax-paying) individuals. This implication is consistent with the Allen, Bernardo, and Welch (2000) argument that managers can appeal to the tax advantage on equity income enjoyed by institutions, leading institutional investors to form tax clienteles conditional on the dividend policies of firms.

\footnotetext{
2 In signaling models such as Ross (1977), institutional holdings can substitute for debt in narrowing the information gap between outside and inside shareholders, leaving firms with less need to signal their quality with costly debt. These models, however, have not received much empirical support.
} 
Thus, tax considerations suggest that higher institutional holdings should be associated with a higher portion of equity in firms' capital structure.

In addition to theories related to agency, information, or taxes, a recent strand of the capital structure literature examines the dynamics of firms' capital structures as determined by the costs of making adjustments (e.g. Leary and Roberts (2005), Strebulaev (2007), and Byoun (2008)), and the relationship between these adjustments and firm characteristics such as cash flows and investment policies (e.g., Faulkender, Flannery, Hankins, and Smith (2012)). If institutions, as a group, have a mitigating effect on firms' agency costs and information asymmetry problems, costly adjustment models imply that, in general, firms with greater institutional holdings will adjust their capital structure more quickly. While this is interesting in its own right, the focus of this paper is on the relationship between institutional investors and the documented heterogeneity in leverage ratios, and not on the relation between ownership structure and the speed of adjustment of capital structure.

Throughout this section we have discussed capital structure theories in conjunction with the premise that institutional investors can affect the capital structure policies of firms. These theories, however, do not exclude the possibility that institutions may also be affected by firms' capital structures. And indeed, prior studies have shown institutional investors to exhibit preferences for certain firm characteristics. In particular, Del Guercio (1996) finds that institutions tend to invest in lower risk firms, while Gompers and Metrick (2001) find that institutions prefer to hold large, liquid firms. Grinstein and Michaely (2005) and Desai and Jin (2011) study institutional preferences for payout policy, with the former finding that institutions prefer dividend-paying stocks over non-dividend-paying stocks, and the latter finding that institutions form tax-based clienteles in relation to payout policy. In terms of corporate governance, McCahery et al. (2010) find that, in general, corporate governance is important to the institutional investment decision, while Hartzell and Starks (2003) find that, more specifically, institutions reveal a preference for firms in which executive compensation exhibits high pay-for-performance sensitivity. Thus, while it may be most intuitive to think of the relationship between institutional investors and capital structure to advance from institutions to firms, we also consider the alternative that institutions choose their investments at least in part because of firms' leverage policies. 


\section{Data, construction of variables, and summary statistics}

Our data consists of all firm-year observations for U.S. incorporated firms in the CRSP-Compustat merged database between 1979 and 2009, excluding American Depositary Receipts, utility companies (SIC codes 4900 - 4999), and financial firms (SIC codes $6000-6999$ ). ${ }^{3}$ The sample is comprised of firms listed on the NYSE, Amex, and Nasdaq, with the requirement that all firm-years have non-missing and non-negative data for total assets, total debt, and market capitalization. ${ }^{4}$ Following Lemmon et al. (2008), we winsorize ratio variables at the one percent level in an attempt to lessen the effects of outliers, and we restrict leverage ratios to the closed unit interval.

Institutional holdings data comes from the Thomson-Reuters Institutional Holdings Database, as reported on Form 13F filed with the Securities and Exchange Commission (SEC). All institutional managers with more than $\$ 100$ million in assets under management are required to file, detailing all equity holdings of more than $\$ 200,000$ or 10,000 shares. Following Grinstein and Michaely (2005) we set institutional holdings equal to $0 \%$ for firms not appearing in the $13 \mathrm{~F}$ database (potentially because the institutional managers do not meet the entire $13 \mathrm{~F}$ filing requirements), and we restrict institutional holdings to the closed unit interval. Our results are unchanged, however, if we remove the observations not appearing in the $13 \mathrm{~F}$ database or allow institutional holdings to exceed $100 \%$ (as occasionally happens due to fiscal/calendar year differences).

After merging the institutional holdings data with the CRSP-Compustat database and removing observations not meeting the aforementioned data requirements, we are left with 130,202 firm year observations across 31 years. Our sample contains an average of 4,200 firms per year, and fluctuates between 3,228 firms in 1979 and 5,741 firms in 1997. Because we only require positive assets, a positive market cap, and non-missing debt, nearly all of the firms in the NYSE are represented each year.

\footnotetext{
${ }^{3}$ This timeframe was chosen because the Thomson-Reuters institutional holdings data begins in 1979.

${ }^{4}$ Our results are robust to alternate specifications in which we require stock price to be at least $\$ 5$ and assets to be at least $\$ 1$ million. Furthermore, multivariable analyses implicitly require non-missing data for all relevant variables, so the number of firm-years used in the various tests fluctuates depending on the specification chosen.
} 
We impose one additional data requirement for our Arellano-Bond (1991) estimations. Since we use lagged levels to instrument for each contemporaneous, differenced equation, we require all firms to appear consecutively for at least four years at some point during our sample period. This excludes firms leaving our sample between 1979 and 1981, and firms entering our sample between 2007 and 2009. After imposing this additional data requirement, we are left with 122,859 firm year observations for our Arellano-Bond tests, for an average of 3,963 firms per year.

We construct our variables in accordance with several important prior studies. The full set of variable definitions can be found in the Appendix, but we highlight our key variables here. We define institutional holdings (Hold) as the ratio of total shares held by institutions at the end of each calendar year to the total number of shares outstanding at the end of the last fiscal year. We similarly define institutional ownership by the institutions holding the five largest positions (Hold5) as a proxy for ownership concentration. While coordination mechanisms exist for institutions to act collaboratively, it still might be that larger, more concentrated institutional investors are more effective at mitigating agency and information asymmetry concerns (Shleifer and Vishny (1986)). In most cases our results do not change when switching between Hold and Hold5, but when the effect is non-negligible, we specifically address it.

Our other primary variable of interest is firm leverage (TDA), which we define as per Frank and Goyal (2009) as the ratio of total debt to the book value of assets. For robustness we repeat our tests with several alternative measures of leverage: total debt to the market value of assets, long-term debt to the book value of assets, long-term debt to the market value of assets, total debt divided by total debt plus stockholder's equity, and total debt less excess cash divided by total assets. ${ }^{5}$ Our results hold when using these alternative measures, and are also robust to the inclusion of off balance sheet operating leases into our definition of leverage (TDLA, as per Graham, Lemmon, and Schallheim (1998)).

The remaining variables are defined in the Appendix. There, we define net debt and equity issuances and issuers as per Fama and French (2005); adjusted return, beta, sales, and a dividend payer dummy as per Grinstein and Michaely (2005); cash cow as per Brav,

\footnotetext{
${ }^{5}$ We define excess cash as cash holdings minus revenue*.02 if cash holdings exceed $2 \%$ of revenue, and zero otherwise.
} 
Graham, Harvey, and Michaely (2005); initial firm leverage as per Lemmon et al. (2008); and assets, change in assets, market cap, profitability, market-to-book, capital expenditures, tangibility, intangible assets, collateral, total payout, a loss making dummy, and a uniqueness dummy as per Frank and Goyal (2009).

Table I presents summary statistics for both the entire sample period and for two nearly equal length subperiods (the earlier subperiod contains sixteen years of data rather than fifteen). Non-ratio measures (market cap, $\log$ (assets), and $\log$ (sales)) are inflationadjusted to 2009 dollars, and increase over time. Table 1 shows that the average publicly traded firm is significantly larger now than it was 30 years ago.

The ratio measures in the table also change substantially over time, including aggregate institutional holdings (Hold) and top-5 institutional holdings (Hold5). Average holdings more than double from the first half of the sample to the second (19\% to $40 \%)$, while top-5 institutional holdings nearly double (11\% to $20 \%$ ). Even these figures, however, understate the current importance of institutional equity investments. In 2009, mean holdings increased to $55 \%$ overall, but jumped to $76 \%$ for firms in the fourth size quintile ( $\$ 1,169$ million average market cap), and $77 \%$ for firms in the fifth and largest size quintile (\$15,279 million average market cap). In value-weighted terms, by year-end 2009, institutions held $71 \%$ of the $\$ 10.6$ trillion dollar market cap for all firms in our sample.

Average leverage, on the other hand, falls from $25 \%$ in the first half of the sample to $22 \%$ in the second half, while leverage including off-balance-sheet (OBS) operating leases falls from $34 \%$ to $29 \%$. This slightly smaller drop (in percentage terms) illustrates the growth in operating leases found in Franzen et al. (2009).

\section{Results}

\section{A. The effect of institutional holdings on leverage}

The implication of traditional capital structure models is that by interacting with frictions such as agency costs and asymmetric information, institutional investors' equity holdings can play a role in the determination of leverage ratios.

To characterize the relationship between institutional holdings and leverage, we must control for other firm characteristics that affect leverage and may be correlated with institutional holdings. To this end, we begin our empirical study with a multivariate re- 
gression with leverage (time $t$ ) as the dependent variable. Since one of our goals is to examine the causal effect of institutional holdings on leverage, we examine how the lagged value of institutional holdings affects leverage (while this is only a partial solution, we later examine the issue more thoroughly). Our additional independent variables are measured at time $(t-1)$, and, aside from institutional holdings, are commonly used in the capital structure literature (see, e.g., Frank and Goyal (2009)): market-to-book, log of assets, profitability, tangibility, median industry leverage, a dividend payer dummy, capital expenditures, collateral, intangible assets, total payout, change in assets, and industry uniqueness. We also control for initial firm leverage, as Lemmon et al. (2008) find leverage ratios to be surprisingly stable over time. Lastly, we include year dummy variables in all of our tests, and in certain specifications, we include firm fixed effects. We opt not to include industry fixed effects in our regressions because Lemmon et al. (2008) find that industry median leverage vitiates the power of the industry fixed effect to explain leverage ratios, and substantially increases the adjusted $R$-squared in the process. None of the results in this paper change, however, if we include industry fixed effects. Table II presents the results of these panel regressions, with $t$-statistics and significance levels reflecting standard errors clustered at the firm level to allow the error term to be heteroskedastic and correlated within firms.

The data in column 1 show that firms with high institutional holdings, on average, have low leverage even after controlling for other firm characteristics. With only year fixed effects as controls, the coefficient on Hold is -0.028 (unreported), and after adding control variables known to explain the variation in leverage, such as initial firm leverage (Initial_TDA) and the median within-industry leverage ratio (Industry_TDA), the absolute magnitude increases to -0.100 (column 1 ). The result is significant at the $1 \%$ level, and is robust to changes in empirical specification, such as using top-5 institutional holdings or restricting the sample to firms with leverage $>10 \%$. In fact the result is even stronger when we use market leverage rather than book leverage, or if we exclude firms with $0 \%$ institutional holdings (generally firms that do not appear on any $13 \mathrm{~F}$ forms).

In column 2 we include a firm fixed effect to control for potential firm-specific omitted variables. While the effect of institutional holdings on leverage somewhat abates, the 
coefficient of -0.068 remains significant at the $1 \%$ level. ${ }^{6}$ In economic terms, the regression estimate in column 1 (2) suggests that an increase in institutional holdings by one standard deviation is associated with a leverage ratio $2.9 \%$ (2.0\%) lower, on average, in the following year. To put that number in perspective, $2.9 \%$ represents approximately $12 \%$ of the average leverage ratio (23.6\%) during our sample period. In fact, after first standardizing all variables to have a mean of 0 and a standard deviation of 1 , the effect of institutional holdings $(-0.133)$ is comparable in magnitude to that of profitability $(-0.147)$ and industry median leverage (0.127), and is twice as strong as tangibility $(0.068)$. The only variables with a considerably stronger effect are assets (0.207) and initial leverage (0.316). Furthermore, we find this effect to be a permanent one. That is, we do not find evidence of a reversal after regressing leverage on the second lag or third lag of institutional holdings (the coefficients remain negative), nor do we find that the second/third lags affect leverage at all when the first lag is included (not reported).

Given that prior research has found both institutional holdings and leverage to vary strongly by firm size (e.g. Gompers and Metrick (2001) and Bennett, Sias, and Starks (2003)), in our next specification we interact holdings with a dummy variable representing each firm's annual market cap quintile to see whether the relation between institutional holdings and leverage varies by firm size. As reported in column 3, we find this interaction to be meaningful even in the presence of a firm fixed effect. The negative relationship persists in all market cap quintiles, although the relationship is only marginally significant in the largest size quintile. In terms of economic magnitude, institutional holdings have the largest effect on leverage amongst medium-sized firms: those in quintiles 2, 3 and 4 . We find that the average effect on leverage of a (quintile-specific) one standard deviation increase in institutional holdings varies between $-0.5 \%$ for the largest firms, and $-1.1 \%$ for the firms in quintile 3. By allowing the relationship between leverage and institutional

\footnotetext{
${ }^{6}$ Lemmon et al. (2008) note that while most coefficients remain significant in a leverage regression with firm fixed effects, the magnitudes of the coefficients shrink considerably (Table V in their paper). We, however, do not find such stark differences between coefficients in our specification with fixed effects and our specification without. The difference between our findings and theirs stems from treatment of the error term. Lemmon et al. impose a first-order autoregressive structure on their error term, and we do not. We do, however, test for serial correlation in the errors using a variant of the Durbin-Watson test derived for use with an unbalanced panel (Bhargava, Franzini, and Narendranathan (1982)), and do not find conclusive evidence in favor of an autoregressive error structure.
} 
holdings to vary by firm size we explain a larger portion of the variation in leverage ratios, increasing our adjusted $R^{2}$ from $32.3 \%$ to $35.0 \%$ without a firm fixed effect, and from $63.9 \%$ to $64.6 \%$ with a fixed effect. Furthermore, our results compare favorably to similar tests encountered in the literature, where adjusted $R^{2} \mathrm{~s}$ in the absence of a firm fixed effect peak at around $30 \%{ }^{7}$

In unreported analysis, we re-estimate columns 1 through 3 after subjecting our dependent variable TDA to a logit transformation. Since leverage is a proportion bounded between zero and one, the regressions in columns 1 through 3 might be misspecified, and performing a logit transformation alleviates any concerns this may cause. Here, and throughout the paper, our results are unchanged when using the transformed, unbounded dependent variable. Consequently, in the remaining tables we report results only for our bounded leverage and institutional holdings variables, as the coefficients on the independent variables have straightforward interpretations. Finally, although we cluster standard errors at the firm level, we re-run the tests in columns 1 through 3 according to the technique outlined in Fama and MacBeth (1973). Our conclusions do not change.

One factor that may affect capital structure is market timing (Baker and Wurgler (2002)). In addition, equity market timing may interact with institutional holdings as well. For example, Alti and Sulaeman (2012) show that firms issue equity after high stock returns only when institutional demand is strong. Their finding might imply that the relationship we find between leverage and institutional holdings is not only because of the effect of institutions on the frictions underlying capital structure models, but rather an artifact of firms timing the market with equity issuances.

We control for this possibility in two ways. First, we include the Baker and Wurgler (2002) external finance weighted average (EFWA) market-to-book ratio (defined in the Appendix) in a regression mirroring the one in Column 1, and our result holds (not reported). Second, to specifically address the findings of Alti and Sulaeman (2012), we include lagged abnormal stock return (realized return relative to the CAPM prediction - defined in the Appendix) on the right hand side of the estimation in Column 4. By controlling for ab-

\footnotetext{
7 In similar regressions, Lemmon et al. (2008) produce an adjusted $R^{2}$ of 30\% with data from 1965 to 2003, while Frank and Goyal (2009) produce adjusted $R^{2} \mathrm{~s}$ of $30 \%, 14 \%, 14 \%$, and $21 \%$ for the 1970's, 1980's, 1990 's, and 2000 to 2003 , respectively.
} 
normal stock return, we estimate the effect of institutional holdings on leverage outside of the context studied in Alti and Sulaeman (2012), and we continue to find that institutional holdings have a negative effect on leverage. In fact, the magnitude of the coefficient actually increases from -0.068 in Column 2 to -0.070 in Column 4, although the sample is slightly smaller (lagged return requires two prior years of pricing data, as opposed to the one prior year required by the variables in Column 2). Furthermore, if we restrict the sample to include only firms that did not have a large abnormal return in the prior year (e.g. if we include only firms with returns in the $25^{\text {th }}$ to $75^{\text {th }}$ percentile), our results hold. Based on these results, we conclude that our findings are not a manifestation of firms timing the market with equity issuances.

A primary motivation for this paper is that institutional investors affect the conflict of interest between outside equity holders and managers. However, a second conflict exists between equity holders and debt holders (e.g., Jensen and Meckling (1976), Myers (1977), and Diamond and He (2011)), and it is unclear whether institutional equity investors have an effect on this conflict. On one hand, greater information-gathering and effective monitoring by institutions reduces the opacity of firm' assets. Indeed, Edmans (2009) shows that blockholders attenuate managers' myopic behavior, making bonds less risky, while Jiang, Li and Shao (2010) find that when institutions are both equity holders and debt holders, the cost of borrowing falls. On the other hand, greater alignment between managers and shareholders can lead to more managerial risk-taking and higher costs of debt (Ortiz-Molina (2006)), particularly in the absence of takeover protections (Cremers, Nair, and Wei (2007)).

In our empirical specifications we control for these potential effects in a variety of different ways. Most broadly, we control for firms' credit ratings to proxy for the effect of institutional holdings on the cost of debt. In addition, we control for the level of managerial equity holdings because Datta, Iskandar-Datta, and Raman (2005) show that managers are more likely to make capital structure decisions in alignment with the preferences of outside equity holders if their own shareholdings are high. And finally, given that the conflict of interest between shareholders and bondholders depends on the corporate governance environment of a firm (Cremers et al. (2007)), we control for the Gompers, Ishii, Metrick (2003) GIM Index and the number of analysts that cover each firm. 
We find that the effect of institutional holdings on leverage persists after controlling for each of these measures. Controlling for credit ratings does not materially change any result, and controlling for the GIM Index does not change our results and significantly reduces the sample size, so we only report the estimates after controlling for insider holdings (column 5) and analyst coverage (column 6). We find that after controlling for insider holdings the effect of institutional holdings on leverage remains negative and significant, even in a regression with firm fixed effects. The coefficient of -0.044 is smaller in magnitude than the -0.068 found in column 2, but the samples are very different since ExecuComp insider holdings data is only available after 1991, and only for S\&P 1500 firms. Overall, we find the effect of institutional holdings on leverage to be quite robust to the potential effect of institutional holdings on the conflict of interest between equity holders and debt holders.

Next, we examine the possibility that the relationship between institutional holdings and leverage stems from important covariates of institutional holdings - analyst coverage and equity liquidity - rather than from the holdings themselves. Chang, Dasgputa, and Hilary (2006) find that firms with more analyst coverage have lower target debt ratios, and that firms with less analyst coverage are less likely to issue equity and more likely to time the market when they do issue. Furthermore, Hennessey and Whited (2005) show that leverage is persistent and negatively correlated with lagged liquidity.

To account for the correlation between institutional holdings and analyst coverage, we follow Chang et al. (2006) and use data from I/B/E/S to define Analyst Coverage as the maximum number of analysts who make annual earnings forecasts in any month during the twelve months prior to fiscal year end, while assuming that firms not covered by I/B/E/S have no analyst coverage. And to account for equity liquidity we include the Amihud (2002) illiquidity measure (defined in the Appendix). We find that institutional holdings remain a significant determinant of leverage after controlling for the negative relationship between analyst coverage and leverage (column 6), and that the relationship is robust to the inclusion of Amihud's liquidity measure (unreported).

To further extend our analysis, we modify our definition of leverage to include offbalance-sheet (OBS) operating leases in column 7. Franzen et al. (2009) provide evidence of a dramatic increase in the use of OBS operating leases over the last past decades, advo- 
cating that a more complete measure of leverage would include OBS leases on both sides of the balance sheet. Furthermore, Rampini and Viswanathan (2010) and Eisfeldt and Rampini (2009) suggest, respectively, that leasing increases firms' debt capacity because "leasing tangible assets requires less net worth per unit of capital" and "repossession of a leased asset is easier than foreclosure on the collateral of a secured loan." As such, operating leases may play a role in the relation between institutional holdings and leverage.

As per Franzen et al. (2009) and Graham et al. (1998), we calculate leases as the capitalized value of non-cancellable OBS operating leases, and incorporate that value into both total assets and total debt. We find that while the relation between holdings and leverage becomes slightly less negative in each size quintile (e.g. from -0.060 for firms in the third size quintile in column 3 to -0.050 for the same firms in column 7), our results are robust to the inclusion of OBS leases. ${ }^{8}$ In fact, our adjusted $R^{2}$ s increase significantly when we include leases. Without leases, the specification in column 1 yields an adjusted $R^{2}$ of $32.3 \%$, but when we add OBS leases into debt and assets the adjusted $R^{2}$ increases to $37.1 \%$ (not reported). Similarly, comparing columns 3 and 7, we see the adjusted $R^{2}$ increase from $64.6 \%$ to $69.0 \%$ when leases are included.

Finally, prior literature suggests that the relation between institutions and frictions such as agency costs and asymmetric information may differ by institution type or investment horizon (Chang et al. (2007)), although it is not clear a priori how this should affect firms' leverage in the aggregate. To examine whether the relationship between institutional holdings and leverage differs by these institutional characteristics we utilize type and horizon classifications as calculated and provided by Brian Bushee on his website. ${ }^{9}$ While we do not report the results of these tests, we find that the relation between institutional holdings and leverage does not particularly vary by institution type. Investment advisers (mutual funds, hedge funds, etc.) have the strongest effect, and the largest holdings, but pension funds, insurance companies, and banks all have a negative and significant effect as well. University and foundation endowments, as well as "miscellaneous" institutions, have an insignificant effect. As for investment horizon, we find that long-term investors ("dedi-

\footnotetext{
${ }^{8}$ The sample in column 6 is different from that in column 3, so we cannot directly compare coefficients. However, when we re-run the TDA regressions using the TDLA sample, the Hold coefficients in the TDA regressions are still meaningfully larger than the Hold coefficients in the TDLA regressions.

${ }^{9}$ http://acct3.wharton.upenn.edu/faculty/bushee/
} 
cated" institutions) and quasi-indexers have a negative and significant effect on leverage, while short-term investors ("transient" institutions) have a negative effect that is only significant in a regression with firm fixed effects. Quasi-indexers have the largest effect, and also have the largest holdings.

So far we have controlled for differences in firm characteristics by including lagged levels of important variables in our regressions, and have alleviated concerns over omitted variables by including firm fixed effects. Estimating the effect of changes in institutional holdings on changes in leverage is another way to control for unobserved heterogeneity and omitted variables, but also allows us to estimate the effect of holdings on leverage while controlling for lagged changes in leverage. To this end, Table III presents the effects of lagged changes in institutional holdings on changes in leverage. The output in column 1 shows that a change in institutional holdings results in a subsequent change in leverage to the opposite direction. The coefficient of -0.014 is significant at the $1 \%$ level, even after controlling for lagged changes in leverage.

The second column of Table III presents the effect of changes institutional holdings on subsequent changes in leverage, with OBS leases added to both debt and assets. The magnitude of the effect is over 50\% larger than in the case without OBS leases, and the coefficient remains significant at the $1 \%$ level even after controlling for lagged changes in leverage. As was the case in levels (Table II), the effect of changes in institutional holdings on changes in leverage is robust to the inclusion of OBS leases.

Overall, our findings thus far lend support to the hypothesis that institutional holdings and debt exist as partial substitutes, rather than complements, in the mitigation of problems stemming from agency costs or information asymmetry. Firms in which institutions have a strong presence tend toward low leverage, and firms in which institutions strengthen their presence are associated with lower leverage. What's more, our results in Tables II and III suggest that the relationship may be of a causal nature rather than simply an association, as we find that firms decrease (increase) their leverage in response to increases (decreases) in institutional holdings. We test this in detail later in the paper.

\section{B. The effect of leverage on institutional holdings}


While most capital structure theories implicitly suggest causality from institutions to firms' leverage, one can think of scenarios, not inconsistent with these theories, in which causality would go in the reverse direction. In fact, several recent papers show institutional investors to exhibit preferences over firm characteristics, establishing a precedent suggesting that firms' capital structure may influence institutional investors' equity holding decisions. In particular, institutions have shown preferences over firm characteristics such as visibility, transaction costs, and volatility (Falkenstein (1996)), payout policy (Grinstein and Michaely (2005); Desai and Jin (2011)), and corporate governance (Ferreira and Matos (2008), and McCahery et al. (2010)). Furthermore, Del Guercio (1996) finds that institutions tilt their portfolios toward "prudent" stocks, which in the context of this paper might imply low-leverage firms.

To test the effect of leverage on institutional holdings we start with a level regression where the dependent variable is institutional holdings, measured at time $t$. The independent variables, measured at time $(t-1)$, are leverage, log sales, beta, annual adjusted return, total payout, market-to-book, a dividend payer dummy (equal to 1 in the event the firm pays a dividend), and year dummy variables. Following Grinstein and Michaely (2005), we select log sales and beta to account for risk, the market-to-book ratio to control for growth opportunities and asymmetric information, and our two payout policy variables because the authors find a relationship between dividend payers and holdings, as well as between repurchase activity and institutional holdings. Table IV presents the effect of leverage on institutional holdings in Panel A, and the effect of changes in leverage on changes in institutional holdings in Panel B.

In Panel A we find that, on average, institutions have higher holdings in lowleverage firms than in high-leverage firms. Without a firm fixed effect (column 1), the result is significant and suggests that a one standard deviation increase in lagged leverage is associated with a $2.5 \%$ decrease in institutional holdings, a figure corresponding to $10 \%$ of the average full-period institutional holdings (24\%). With a firm fixed effect (column 2), the effect abates by around 30\%, although it remains significant. In addition, we verify that our results are robust to the inclusion of OBS operating leases into our definition of leverage, are not driven by a time trend (we repeat our tests for several subperiods), and are not 
due to the possible misspecification of institutional holdings (we re-run the tests after subjecting Hold to a logit transformation).

As an alternative to a fixed effects regression, we test the relation between institutional holdings and leverage in first differences rather than in levels, and include lagged changes in institutional holdings as a control. The results are reported in Panel $\mathrm{B}$. We find that, on average, institutional holdings decrease after firms increase their leverage, regardless if leverage is calculated with or without OBS operating leases (we do not report the test that includes OBS leases). Even after controlling for the lagged change in institutional holdings, the $\triangle T D A$ coefficient of -0.037 is significant at the $1 \%$ level.

\section{Addressing the issue of endogeneity}

So far we have found that institutional holdings negatively affect leverage, and that leverage negatively affects institutional holdings. While regressions on lagged, differenced variables are an important step toward addressing the issue of endogeneity, they do not solve the issue. In this subsection we employ three techniques to remove the potential feedback effect of leverage on holdings: two separate instrumental variables (IV) approaches and a semi-natural experiment. Our first IV approach is a dynamic panel estimation similar to the one developed by Holtz-Eakin, Newey, and Rosen (1988) and Arellano and Bond (1991), while our second IV approach is a classical two-stage least squares estimation using mutual fund flow induced trading as an instrument for firm-specific institutional holdings. Finally, our third approach is a semi-natural experiment in which addition to the S\&P 500 Index provides an exogenous shock to institutional holdings.

\section{C.1. Difference GMM}

The Arellano and Bond (1991) "difference" generalized method of moments estimator fits linear models with one dynamic variable and additional controls on short, wide $N$ x $T$ panels. It is designed to handle fixed effects and endogeneity of regressors by using past values of endogenous variables to instrument for current changes in those variables. The procedure avoids dynamic panel bias (Nickell (1981)), and deals with potential biases caused by the correlation of institutional holdings and leverage over time. 
We run two separate estimations, one with leverage as the dependent, dynamic variable, and one with changes in institutional holdings as the dependent, dynamic variable. The models are specified as follows:

$$
\begin{gathered}
\text { Leverage }_{i t}=\alpha \text { Leverage }_{i, t-1}+\beta \text { InstHoldings }_{i, t-1}+\mathbf{x}_{\mathrm{i}, \mathrm{t}-1}^{\prime} \theta+\varepsilon_{i t} \\
\text { InstHoldings }_{i t}= \\
\text { InstHoldings }_{i, t-1}+\delta \text { Leverage }_{i, t-1}+\mathbf{x}_{\mathrm{i}, \mathrm{t}-1}^{\prime} \tau+\pi_{i t} \\
\varepsilon_{i t}=\mu_{i}+v_{i t} \text { and } \pi_{i t}=\varphi_{i}+\omega_{i t} \\
\mathrm{E}\left[\mu_{i}\right]=\mathrm{E}\left[v_{i t}\right]=\mathrm{E}\left[\mu_{i} v_{i t}\right]=0 \text { and } \mathrm{E}\left[\varphi_{i}\right]=\mathrm{E}\left[\omega_{i t}\right]=\mathrm{E}\left[\varphi_{i} \omega_{i t}\right]=0
\end{gathered}
$$

where $i$ indexes the firm, $t$ indexes time, $\mathbf{x}$ is a vector of controls, $\mu_{i}$ and $\varphi_{i}$ are the firm fixed effects, and $v_{i t}$ and $\omega_{i t}$ are the idiosyncratic shocks, which are orthogonal to $\mu_{i}$ and $\varphi_{i}$, respectively. The vector $\mathbf{x}$ can contain variables that are endogenous, predetermined, and exogenous, as well as deeper lags of the dependent, dynamic variable. The estimation is a two-step procedure: first, variables are differenced to remove firm fixed effects, and second, a GMM estimator instruments endogenous variables with their available lags in levels.

Table V presents the estimates from our Arellano-Bond estimations with leverage as the dependent, dynamic variable in Panel A, and institutional holdings as the dependent, dynamic variable in Panel B. In both panels, the internal instruments begin at the third lag to avoid problems stemming from autocorrelated error terms, and we collapse our instrument matrices to eliminate problems associated with excessive instruments.

The results in Panel A show a strong, negative effect of institutional holdings on leverage. The coefficient on Hold is significant at the 1\% level (column 1), even after controlling for other important determinants of leverage, autocorrelation in institutional holdings and leverage, time varying idiosyncratic shocks, and time trends. In addition, the result is robust to the inclusion of OBS operating leases into our definition of leverage (not reported in the table).

In the specification estimated in column 2, we substitute Hold5, the holdings of the five largest institutional investors, for total holdings (Hold). The result is again significant and is even stronger than the one presented in column 1, with the absolute magnitude of 
the coefficient increasing from -0.148 to -0.183 . Because we are testing a causal relationship, it makes intuitive sense that the top five institutional investors have a more significant impact on leverage than all institutions combined, as they likely have the highest incentives to monitor, collect information, and engage in activism.

We test the strength of our instruments with the procedure outlined in Stock and Yogo (2005) and return a Kleibergen-Paap F-statistic of 68.0, which exceeds all Stock and Yogo (2005) instrumental variable critical values for weak identification. Both specifications presented in Panel A pass the Arellano-Bond test for second (third) order autocorrelation in levels (differences). In sum, our instruments pass tests for both instrument validity and strength. Finally, while the specification presented in column 1 fails the Hansen test for joint validity of the full instrument set, the $J$-test, the specification in column 2 using top-5 holdings passes easily.

Panel B, however, tells a different story. While our previous regression tests in levels and in differences show leverage to have a negative effect on institutional holdings, this effect disappears once we remove the effect of holdings on leverage. With the institutional holdings as the dependent, dynamic variable in column 1 , the coefficient on TDA is, at 0.012, insignificantly different from zero. Similarly, after substituting top-5 institutional holdings for total holdings, we find in column 2 that the effect of leverage is still insignificant. Both specifications pass the Hansen J-test, suggesting the validity of the full set of instruments, as well as the Stock and Yogo tests for instrument weakness. ${ }^{10}$

All told, the results in Table $V$ suggest that after removing the endogenous components of the relationship between institutional holdings and leverage, institutions affect firms' leverage through their holdings, but changes in leverage do not lead institutions to alter their holdings.

\section{C.2. Two-Stage Least Squares}

Next, we estimate the extent to which institutional holdings affect capital structure using an instrumental variable and linear two-stage least squares. To remove the potential

\footnotetext{
10 In an alternative specification to Panel B, column 1, we restrict our instrument matrix to include only one lagged change in institutional holdings, and also incorporate our instrumental variable from the next section, MFFlow, into the estimation. Leverage continues to have an insignificant effect on institutional holdings.
} 
feedback effect of leverage on institutional holdings we need an instrument for institutional holdings that is unrelated to the unobserved factors that affect firms' financial leverage. Our instrument, implied trades induced by mutual fund outflows (MFFlow), is borrowed from Edmans, Goldstein, and Jiang (2011). ${ }^{11}$

The idea behind the instrument is that outflows by mutual fund investors lead to changes in mutual fund portfolio holdings, as the funds must sell a portion of their holdings to repay investors who wish to redeem their investment. If, however, in response to investor outflows, mutual funds trade based on information related to firms' capital structures, actual trades may not be a valid instrument for institutional holdings. To alleviate this concern, we use implied trades constructed from investor flows and previously disclosed portfolio holdings. Implied trades are likely to satisfy the exclusion restriction because mutual fund investors' decisions to accumulate or divest shares in a fund are unrelated to the capital structure policies of the individual firms held by the fund. After all, if the investors cared to, they could trade the stocks of the individual firms rather than trade mutual fund shares. Thus, implied trades constructed using mutual fund flows will lead to changes in institutional holdings that may affect capital structure, but that are not motivated by it.

One potential concern with using fund flow induced trading as an instrument for institutional holdings is that the price pressure resulting from excessive fund flows may lead firms to time the market with debt and equity issuances, thus creating a spurious relationship between institutional holdings and leverage. Gao and Lou (2011) investigate this issue and find some support for market timing considerations, predominately in firms more financially constrained. The magnitude of the effect they find, however, is very small. Specifically, Gao and Lou find that a one standard deviation increase in flow induced price pressure is associated with a decrease in the subsequent debt to equity ratio of approximately 5.6 basis points. We, on the other hand, find in Table II that a one standard deviation increase in institutional holdings is associated with a 228 basis point decrease in leverage, and if we run the regression using the debt to equity ratio in place of leverage, we find the negative association to be greater than 1,100 basis points. With the economic effect of institutional holdings on capital structure to be nearly 200 times larger than the economic

\footnotetext{
${ }^{11}$ Edmans et al. (2011) study the impact of stock prices on takeover probabilities, and note that price may be
} endogenous, necessitating an instrumental variables approach. 
effect of flow induced price pressure, the concern that market timing considerations generate a spurious relationship between institutional holdings and leverage appears to be minor.

The instrument we use, MFFlow, is the firm-specific annual dollar change in holdings implied by mutual fund investor outflows and previously disclosed mutual fund holdings. Specifically, for firm $i$ in quarter $t$,

$$
\text { MFFlow }_{i, t}=\sum_{j=1}^{m} \frac{F_{j, t} \times S H A R E S_{i, j, t-1} \times P R C_{i, t-1}}{T A_{j, t-1} \times V_{i, t}},
$$

where $F_{j, t}$ is the total outflow experienced by fund $j$ in quarter $t, T A_{j, t-1}$ is fund $j$ 's total assets at the end of the previous quarter, SHARES $S_{i, j} \mathrm{x} P R C_{i, t-1}$ is the dollar value of fund $j$ 's holdings of stock $i$, and $V O L_{i, t}$ is the total dollar trading volume of stock $i$ in quarter $t$. The summation is over funds $j$ for which quarterly investor outflows equal or exceed $5 \%$ of fund $j$ 's total assets (i.e. $-F_{j, t} / T A_{j, t-1} \geq 5 \%$ ). Edmans et al. (2011) argue that the impact of outflow on prices will depend on a stock's liquidity, and as such scale MFFlow by trading volume. Although this concern is less relevant for our paper, we proceed in kind. Finally, to complete the calculation, we sum MFFlow across the four quarters in a given calendar year.

Table VI presents the effect of institutional holdings on leverage, estimated via twostage least squares. ${ }^{12}$ We find that after removing the feedback effect of leverage on institutional holdings, the effect of holdings on leverage increases substantially. Our results show that a one standard deviation increase in institutional holdings leads to a statistically and economically significant decrease in leverage of $8.0 \%$, as compared to $2.9 \%$ without instrumentation (column 1, Table II). The result is supported by a first stage F-statistic of 358.21, which his easily large enough to reject the hypothesis that the instrument is weak (Stock and Yogo (2005)).

\footnotetext{
12 Due to data constraints, the sample in Table VI differs slightly from that in Table II. MFFlow, obtained from Alex Edmans's website, is calculated annually between 1980 and 2007, inclusive, and as such, 2008 and 2009 are excluded from the tests in Table VII. Repeating column 1 in Table III using this sample, however, yields a very similar coefficient for institutional holdings of -0.080 .
} 


\section{C.3. S\&P 500 Index Inclusion}

As our final method of controlling for the potential feedback effect of leverage on institutional holdings, we conduct a semi-natural experiment that utilizes the exogenous shock to institutional holdings associated with the inclusion of a firm into the S\&P 500 Index (Pruitt and Wei (1989)). Aghion, Van Reenen, and Zingales (2008), who also use addition to the S\&P 500 Index as an instrument for institutional holdings, mention three sources for this increase: index funds, non-indexers that benchmark against the Index, and institutions appealing to the implied endorsement of broad indexing to satisfy prudent man restrictions.

S\&P 500 inclusion is a valid instrument for institutional holdings because it is considered by Standard and Poor's to be an information-free event. When a change is made to an S\&P equity index, Standard \& Poor's states in its press release that "company additions to and deletions from an S\&P equity index do not in any way reflect an opinion on the investment merits of the company." Furthermore, Neubert (1985) describes the criteria for S\&P 500 selection to be: "size, industry classification, capitalization, trading volume/turnover, emerging companies/industries, and responsiveness of the movements of stock price to changes in industry affairs," all of which are public information already factored into firm valuations and metrics.

As with mutual fund flow induced trading, market timing considerations can potentially render S\&P 500 inclusion an invalid instrument. That is, as Standard \& Poor's aims to construct an index that is both representative and stable, it often chooses large firms with good past performance. Given this, firms that are added to the index often experience large stock returns in the quarters preceding inclusion. It could be the case, then, that firms take advantage of the large returns and issue equity while stock prices are high, in turn lowering leverage and creating a spurious negative relationship between institutional holdings and leverage. In fact, Alti and Sulaeman (2012) find that firms time the market to issue equity only when they have both a favorable stock price and high institutional demand for their shares.

While we are unable to completely eliminate this possibility, we employ a propensity score matching technique (Rosenbaum and Rubin $(1983,1985)$, and Heckman, Ichimura, and Todd (1997)) in which we match each firm that enters the S\&P 500 to a control firm 
with the closest propensity score based on the cumulative CAPM-adjusted stock return for the quarter before inclusion and the quarter of addition. We also match on size, market-tobook, leverage, institutional holdings, asset growth, and liquidity, and we force matches to be in the same industry at the same time period (year-quarter).

For our S\&P 500 natural experiment, we use quarterly data from Compustat, and count 526 first-time additions to the Index between 1979 and 2009 (excluding financial firms and utilities). As we require non-missing leverage for four quarters after addition, we lose 75 observations of the 526 (including 24 from firms that were added in 2009 - the final year in our sample). Furthermore, since we match on lagged return, we require two quarters of non-missing prices prior to addition, decreasing our sample by the 8 firms that were added in the first two quarters of 1979 - the first year in our sample. Finally, we lose 28 observations due to missing data required for our matching procedure (in particular, the components of Amihud's illiquidity measure), leaving us with 415 S\&P 500 additions between the third quarter of 1979 and 2008.

To be eligible for the control group we require that a firm has never been in the S\&P 500 Index, that it has been dropped from the Index at least one year prior to becoming a match, or that it has been in the Index for at least one year before becoming a match. Excluding firms in the S\&P 500 from the control group would make finding appropriate matches more difficult, but it would also make it easier to generate results in a differencein-difference framework. Because finding quality matches is important, we include S\&P 500 firms in the control group and in doing so subject ourselves to a difficult testing environment. This matching procedure yields a control group in which 209 firms are members of the S\&P 500 Index, and 206 firms are not. However, in an alternate procedure, we force all matches to be members of the S\&P 500 Index to control for a possible S\&P 500 fixed effect, and our results hold. With our treatment and control samples now constructed, we conduct both a difference-in-difference paired $t$-test and a difference-in-difference regression test. The results are presented in Table VII.

Panel A of Table VII presents summary statistics one quarter before S\&P 500 addition for both the treatment and control groups. The groups are very similar. We see that the treatment group is slightly larger in terms of market capitalization and total assets, although the groups have equal market-to-book ratios. Furthermore, the treatment group has 
marginally higher institutional holdings and leverage before addition to the Index. While not reported, we find that between the quarter before addition and the quarter of addition, institutional holdings increase by $3.4 \%$, on average, for the treated firms, and only $0.6 \%$, on average, for the control firms. The difference between these changes is significantly different from zero. Importantly, the cumulative abnormal return in the quarter prior to addition and the quarter of addition is actually higher for the control group than for the treatment group, helping to assuage concerns that the leverage decrease we find stems from the market timing considerations studied in Alti and Sulaeman (2012).

In Panel B we present the results of a difference-in-difference paired $t$-test. We compare the mean difference in leverage between the treatment and control groups in the quarter prior to addition to the mean difference one year after addition, which should provide firms with enough time to alter their capital structure policies in response to the increase in institutional holdings caused by S\&P 500 addition. We find that the mean difference between treatment and control groups shrinks by (a statistically significant) 0.015 , from 0.017 before addition to 0.002 after addition. The mean difference produces a $t$ statistic of -2.061, indicating a change in leverage stemming from the increase in institutional holdings that results from index inclusion. ${ }^{13}$

Finally, in Panel C we present the results of our regression analysis. For this test we create two new dummy variables, one indicating whether the firm joins the S\&P 500 (Treatment = 1 in this case), and the other indicating whether the time period is before or after inclusion (Post = 1 after inclusion, for both the treatment firms and the matched sample). The difference-in-difference estimator of interest is the interaction of these two dummy variables, Treatment*Post. In order to isolate the effect of S\&P 500 addition, we restrict our sample to the period one year before inclusion to one year after inclusion ( 9 quarters per firm) for both the treatment and control groups. In the regression we control for the determinants of leverage used in Table II, as well as lagged and contemporaneous adjusted return and (Amihud's) illiquidity to mitigate concerns related to market timing.

\footnotetext{
13 To further ensure that the differential change in leverage between the treatment and control group is indeed due to the inclusion into the S\&P 500, we use the following placebo test: We look back two years before addition to the S\&P 500, and repeat our difference-in-difference paired $t$-test from Panel B (using the same firms in the treatment and control groups). We find the mean difference in leverage (and institutional holdings) between the treatment and control groups before and after this particular quarter to be indistinguishable from zero.
} 
We find the effect of Treatment*Post on leverage to be negative and significant, with a coefficient of -0.015 and $t$-statistic of -2.00 . The result complements our findings in Panel $B$, and points to a significant difference in the change in leverage between the treatment and control groups after index inclusion, even after controlling for other known determinants of leverage and market timing forces. The $1.5 \%$ change in leverage is economically, as well as statistically significant, as it represents $7.7 \%$ of the average treatment firms' preevent leverage (19.4\%), and is already being measured above-and-beyond the "natural" change in leverage in the control firms.

Taken together, we have presented three different tests: Arellano-Bond, 2SLS, and a semi-natural experiment using inclusion to the S\&P 500 Index. Those tests differ dramatically in their sample size, and the nature of the tests themselves differs across experiments. Nonetheless, all the three tests support the same conclusion: institutional holdings have a causal negative influence on capital structure. In addition, our dynamic panel results suggest that institutions do not unequivocally change their holdings in response to changes in leverage. We interpret this as evidence that institutions carry out activities that either directly or indirectly mitigate agency or informational frictions regardless of the existing internal mechanisms for doing do. Institutions monitor, for example, for their own purposes, and do not decrease their investment in a firm just because the firm increases its leverage and hence further bonds managerial activities. It is up to firms, then, to decrease costly internal investor protection mechanisms when large institutional investors provide an alternative external investor protection mechanism.

\section{Agency Costs, Asymmetric Information, or Taxes?}

We posited that institutional investors may have an effect on firms' capital structure because they are uniquely qualified to interact with frictions that, at least in part, determine firms' leverage ratios. Our results thus far support both agency and asymmetric information models that predict changes in institutional holdings will results in opposite changes in leverage. This evidence, however, is also consistent with tax considerations because of the relative tax advantage enjoyed by institutional investors over individual investors on equity income. In this section, we try to shed some light on the relative importance 
of these frictions (asymmetric information, agency, and relative taxation) for the negative relation between institutional holdings and leverage.

To this end, we identify firms likely to face high levels of agency costs and firms likely to suffer from high degrees of information asymmetry. We then compare the effect of institutional holdings on leverage between the groups. Firms particularly prone to high agency costs are, in general, large, profitable firms, with few growth opportunities relative to their cash holdings. On the other hand, firms commonly prone to information asymmetry problems are generally small, young, cash-strapped firms with relatively many growth opportunities.

We sort firms annually into market cap quintiles and market-to-book quintiles, as the market-to-book ratio proxies for growth opportunities. We then classify "Small" firms as firms in market cap quintiles 1 and 2, and "Large" firms as firms in market cap quintiles 4 and 5. Similarly, we classify "Low" growth opportunity firms as firms in market-to-book quintiles 1 and 2, and "High" growth opportunity firms as firms in market-to-book quintiles 4 and 5. Using these classifications, we define agency firms as firms in both the "Large" and "Low" categories, and asymmetric information firms as firms in both the "Small" and "High" categories. Separating firms in this manner allows us to test whether the relationship between institutional holdings and leverage is driven by one friction in particular.

Panel A of Table VIII reports the results of this test. While we find institutional holdings to be a negative and significant determinant of leverage for both types of firms, the relation is considerably stronger for asymmetric information firms (column 1). The coefficients of -0.147 and -0.050 for asymmetric information and agency firms, respectively, represent changes of $-2.1 \%$ and $-1.4 \%$ relative to a one standard deviation increase in lagged institutional holdings. To give those numbers some perspective, $2.1 \%$ represents $9.0 \%$ of average leverage for asymmetric information firms (23.3\%), while 1.2\% represents $5.1 \%$ of average leverage for agency firms $(27.4 \%)$.

The specifications in columns 1 and 2 include a firm fixed effect, and the results are robust to alternate definitions of Large-Low and Small-High, as well as to alternate categorizations in which we replace Small/Large with a "cash cow" indicator (not reported in the table). Following Brav et al. (2005), we define cash cow firms as profitable firms with a 
strong credit rating (A or better) and a P/E ratio lower than the median $\mathrm{P} / \mathrm{E}$ ratio among profitable firms with a strong credit rating.

Next, we extend this analysis by estimating the effect of holdings on leverage in a dynamic panel separately for agency and asymmetric information firms. The results in columns 3 and 4 support and extend those in columns 1 and 2. That is, in a dynamic panel, institutional holdings only affect firms prone to asymmetric information problems (column 3), as the effect of institutional holdings on leverage is negative but insignificant for firms prone to agency costs (column 4). For robustness, we also run the specifications in columns 1 and 2 in first-differences, and alternatively combine the tests into one regression with a dummy variable designating agency or asymmetric information firms, and obtain complementary results (not reported in the table).

The results in Panel A suggest that information asymmetry is the dominant friction behind the negative relationship between institutional holdings and leverage. The tax advantage of institutional investors, however, implies a relationship in the same direction. Consequently, we employ a semi-natural experiment to address whether tax considerations play a role in the relationship between institutional holdings and leverage. Specifically, we test whether the tax advantage over equity income for institutional investors compared to individual investors drives the negative relation between institutional holdings and leverage. The Jobs and Growth Tax Relief Reconciliation Act of 2003 dramatically lowered the tax rate on equity income for individual investors, and diminished the relative tax advantage enjoyed by institutional investors. If tax considerations are the driving force behind our results thus far, we should see a weaker effect of institutional holdings on leverage after 2003 than before.

To test this hypothesis we restrict our sample to the years 2000 to 2006, excluding 2003, and construct two new institutional holdings variables, Hold_00-02 and Hold_04-06, to test the relationship between institutional holdings and leverage pre- and post-tax break. The results of this test are reported in Panel B. Both coefficients are negative and significant, -0.077 for the pre-2003 period and -0.086 for the post-2003 period, and an Ftest with a p-value of 0.401 reveals that they are insignificantly different from one another. The results in Panel B suggest that tax considerations are not behind the negative relationship between institutional holdings and leverage. In unreported analysis, we re-run the 
test in Panel B using first differences as opposed to levels, and we confirm that we cannot reject the equality of the coefficients before and after the 2003 tax breaks were introduced. Furthermore, the result is robust to the inclusion of leases into the definition of leverage.

\section{E. How do firms change their leverage?}

We have established that changes in institutional ownership negatively affect leverage ratios. Next, we investigate the nature of this process. That is, how do firms change their capital structure in response to, say, an increase in institutional ownership? Is it done by issuing more equity, repurchasing fewer shares, or by decreasing net debt? We examine the relation in terms of the probability of an issuance as well as the size of issuances.

We define equity issuance and debt issuance in accordance with Fama and French (2005) and Lemmon et al. (2008), among others. Equity issuance (\% Change Equity) is the product of the split-adjusted change in shares outstanding and the split-adjusted average stock price, normalized by total assets at time $(t-1)$. Consequentially, a firm is an equity issuer (Equity Issue $=1$ ) if \% Change Equity $>1 \%$, and an equity repurchaser (Equity Repo $=$ 1 ) if \% Change Equity $<-1 \%$. Similarly, debt issuance (\% Change Debt) is the change in total debt (long-term + short-term) normalized by total assets at time $(t-1)$. Finally, the net change in capital structure (\% Change Net Debt) is simply \% Change Debt - \% Change Equity, and a firm is a net debt issuer (Net Debt Issue $=1$ ) if \% Change Net Debt $>0$.

To test the effect of institutional holdings on issuance decisions, we run logistic regressions separately for equity issuances, equity repurchases, and net debt issuances, with lagged changes in institutional holdings as our primary independent variable. In these tests we include the control variables, in first differences, from Table IV, as well as lagged annual adjusted return and beta to capture possible market timing effects. The results of our logistic regressions are presented in the first three columns of Table IX.

We find that an increase in institutional holdings is associated with a higher probability of a firm being an equity issuer in the following year (column 1), and a lower probability of a firm being an equity repurchaser in the following year (column 2). Both results are statistically significant at the $1 \%$ level after clustering standard errors by firm. The logit coefficient of 1.409 in column 1 implies that a one standard deviation increase in the change in institutional holdings is associated with a $14.8 \%$ increase in the odds of a firm 
being an equity issuer in the following year. In terms of probabilities, nearly $39 \%$ of the firm-year observations in column 1 have equity issuances. Thus, increasing the odds of equity issuance by $14.8 \%$ translates to a $3.3 \%$ increase in the probability of the average firm in our sample being a net equity issuer. Similarly, the logit coefficient of -0.368 in column 2 implies that a one standard deviation increase in the change in institutional holding leads to a $0.4 \%$ decrease in the probability of the average firm in our sample being an equity repurchaser during the following year. Our results complement those of Chang, Chen, and Dasgupta (2011), who report that the likelihood of equity issuances increases with the percentage of shares held by short-term institutional investors.

Column 3 presents the effect of changes in institutional holdings on the probability of a firm changing its capital structure by issuing more debt than equity in a given year (Net Debt Issue = 1). $40 \%$ of the firm-years in our sample experience a net change in capital structure in this direction. In column 3 we find that an increase in institutional holdings leads to a lower probability of a firm issuing more debt than equity. Specifically, the coefficient of -0.353 suggests that a one standard deviation increase in the change of institutional holdings leads to a $0.8 \%$ decrease in the probability of the average firm changing its capital structure by issuing debt above and beyond its equity issuances.

For robustness, we redefine equity issuances using a $5 \%$ cutoff rather than a $1 \%$ cutoff in order to exclude minor fluctuations due to stock option plans, conversion of bonds, etc. Although these results are not reported, we find an even larger effect of institutional holdings on equity issuances and repurchases, and the effect remains statistically significant. In addition, we re-estimate the regressions in columns 1 through 3 using top-5 institutional holdings rather than aggregate holdings, and our results are unchanged. Finally, we estimate an alternate specification in which we define equity issuance using a deal-based dummy variable constructed using issuance data from SDC, and our results are qualitatively unchanged.

Next, we examine the effect of changes in institutional holdings on the size of equity and net debt issuances (columns 4 and 5, respectively). There is no column specifically for repurchases because the dependent variables in this panel are simply net changes, and as such can be positive or negative.) Column 4 compliments our findings in column 1, as we find that changes in institutional holdings are related not only to the probability of an equi- 
ty issuance, but also to the size of equity issuances as a percentage of total assets. The coefficient of 0.061 is significant at the $1 \%$ level.

While we test the effect of changes in institutional holdings on changes in leverage in Table II (and find a negative relation), the tests in Table IX are different. Here, we fix the denominator (total assets) and look explicitly at changes in equity and net debt outstanding rather than at the change in the leverage ratio. Whereas before our tests allowed us to see whether or not firms change their leverage in response to changes in institutional holdings, the tests in Table IX allow us to see how firms change their leverage. Thus, in column 5 we estimate the impact of a change in institutional holdings on the net change in capital structure (\% Change Debt - \% Change Equity). We find institutional holdings to be strongly negatively related to our measure of net debt issuance, indicating that when firms decrease their leverage in response to an increase in institutional holdings, they do so primarily by issuing equity rather than by decreasing debt.

We also find that increases and decreases in institutional holdings have symmetric effects on equity and net debt issuances. For example, our results indicate that firms both decrease their net debt issuances after an increase in institutional holdings, and increase their net debt issuances after a decrease in institutional holdings. (These results are not tabulated).

In sum, in this section we show that changes in institutional holdings have a positive and significant effect on the probability and size of subsequent equity issuances, both in gross terms and net of debt issuances. However, in unreported results, we also examine whether changes in debt or equity issuances in year $t$ affect institutional holding in year $t+1$. We find no evidence that institutional holdings are affected by changes in equity, debt, or net debt, reinforcing the direction of causality from institutions to firms as far as capital structure is concerned.

\section{Conclusion}

In this paper we analyze whether institutional holdings influence capital structure decisions, and whether firms' financial leverage affects institutional investors' decisions to hold their equity. Theories of capital structure imply that firms choose their leverage in response to market frictions such as agency costs and asymmetric information. Meanwhile, 
institutional monitoring and information-gathering affect firms' agency costs and information environment, opening channels through which institutions may influence firms' choices of leverage. In the agency framework, institutional investors serve as an external disciplinary mechanism for management, lessening the need for internal disciplinary mechanisms such as debt. In the asymmetric information framework, institutional investors decrease information asymmetry and reduce the adverse selection costs of equity, serving to decrease the amount of debt needed for signaling equilibriums, and to lower the cost of equity relative to debt.

We find a negative relationship between leverage and institutional holdings. That is, firms with a large percentage of their shares held by institutions, on average, have relatively low leverage ratios. We also find that changes in institutional holdings are associated with changes in leverage in the opposite direction (and vice versa). To establish causality, we use three techniques to adjust for the endogenous components of the relationship between institutional holdings and leverage. In an Arellano-Bond dynamic panel estimation that utilizes internal instruments (lagged levels) for both changes in leverage and changes in holdings, we find that an increase in institutional holdings leads to a decrease in leverage, but that a change in leverage does not lead to a change in holdings. In a complementary test using two-stage least squares and implied trades induced by mutual fund outflows as an instrument for institutional holdings (Edmans et al. (2011)), we isolate the effect of institutional holdings on leverage ratios and again find a significantly negative relationship. Finally, we confirm the negative effect of holdings on leverage using the positive shock to institutional holdings that results from S\&P 500 Index inclusion as treatment in a seminatural experiment. While the techniques are different, and the sample sizes vary dramatically across experiments, the results consistently suggest that institutional holdings negatively affect firms' financial leverage, but that firms' leverage does not unequivocally affect institutional holdings.

With tests that allow us to characterize how firms lower their leverage in response to changes in institutional investment, we find that as institutional holdings increase, firms become more likely to issue equity, while the probability of debt issuance is unchanged. Furthermore, we find that the size of equity issuances are related to changes in institutional holdings, both in gross terms and net of debt issuances, suggesting that in response to 
changes in institutional holdings, firms alter their capital structure predominantly through equity issuances.

Our results are strongly supportive of capital structure theories that predict a substitutive relationship between leverage and institutional holdings. Using tests that differentiate between firms prone to agency costs and firms prone to asymmetric information problems, we provide evidence that institutions most strongly influence capital structure through their effect on information asymmetry. Furthermore, the preferential tax treatment of institutional investors as equity holders also suggests an increase in equity relative to debt as institutional holdings increase. However, we find no evidence that tax considerations play a role in this relationship.

Finally, our results suggest that significantly different motives underlie the interaction between institutions and dividends (Grinstein and Michaely (2005)) and the interaction between institutions and leverage (this paper). Grinstein and Michaely (2005) show that institutions do not affect firms' payout policies, but that changes in payout policies affect institutional holdings. Moreover, they show that the interaction is most pronounced in large firms and firms that are cash cows, consistent with the monitoring role of institutions. We, on the other hand, find that institutions do affect leverage, but that changes in leverage do not unambiguously affect institutional holdings. Furthermore, we find that the interaction is most pronounced in small, growth firms, in line with the notion that institutional investors reduce asymmetric information, in turn inducing firms to reduce leverage. These contrasting findings may, perhaps, point not only to different interactions between institutional holdings and various financial policies, but also to differing roles played by dividends and leverage in resolving asymmetric information and agency conflicts between management and outside equity holders. 


\section{Appendix}

\section{A. Variable Definitions}

Leverage (TDA) is the ratio of total debt (DLTT+DLC) to assets (AT)

Leverage including leases (TDLA) is the ratio total debt (DLTT+DLC) plus the present value of off balance sheet (OBS) non-cancelable operating leases (Oplease) to assets $(\mathrm{AT}+$ Oplease $)$. Oplease is calculated as:

$$
\text { Oplease }=\operatorname{RentExp}{ }_{0}+\sum_{t=1}^{5} \frac{M L P_{t}}{\left(1+K_{d}\right)^{t}},
$$

where RentExp $p_{0}$ is the current year rental expense (XRENT), $M L P_{t}$ is the minimum lease payments for years $t=1, \ldots, 5$ (MRC1, MRC2, MRC3, MRC4, MRC5), and $K_{d}$ is the cost of debt capital (set to 10\% following Graham, Lemmon, and Schallhem (1998)).

Institutional holdings (Hold) is the ratio of total shares held by institutions to the total number of shares outstanding (CSHO)

Institutional holdings, top-5 (Hold5) is the ratio of the total shares held by the institutional investors with the five largest positions to the total number of shares outstanding (CSHO)

Log of assets (Assets) is the natural logarithm of assets (AT)

Change in log assets (ChgAssets) is the annual change in log assets (AT)

Market cap (MktCap) is the price (PRCC_F) times the total number of shares outstanding (CSHO)

Log of sales (Sales) is the natural logarithm of sales (SALE)

Profitability (Profit) is the ratio of operating income before depreciation (OIBDP) to assets (AT)

Market-to-book ratio $(M k t B k)$ is the ratio of market value of assets (MVA) to book assets (AT). MVA is the sum of the market value of equity (PRCC_F*CSHPRI) plus debt in current liabilities (DLC) plus long-term debt (DLTT) plus preferred-liquidation value (PSTKL) minus deferred taxes and investment tax credit (TXDITC).

Capital expenditure (Capex) is the ratio of capital expenditure (CAPX) to assets (AT)

Tangibility (Tang) is the ratio of net property, plant, and equipment (PPENT) to assets (AT) Intangible assets (Intang) is the ratio of intangibles (INTAN) to assets (AT) 
Collateral (Colltrl) is the ratio of inventory (INVT) plus net property, plant, and equipment (PPENT) to assets (AT)

Dividend paying dummy (Dividend) is a dummy variable taking the value of one if common dividends (DVC) is positive, and zero otherwise

Payout (Payout) is the ratio of common dividends (DVC) plus purchases of common and preferred stock (PRSTKC) to assets (AT)

Loss making dummy (Losses) is a dummy variable taking the value of one if Profit is negative, and zero otherwise

Uniqueness dummy (Unique) is a dummy variable taking the value of one if the SIC code of the firm is between 3400 and 4000 , and zero otherwise

Cash cow (CashCow) is a dummy variable taking the value of one if a firm is profitable (Profit $>0$ ), has a credit rating of A or better (SPLTICRM between 2 and 8), and a P/E lower than the median P/E among profitable firms with a credit rating of A or higher, and zero otherwise

Median industry leverage (Industry_TDA) is the median ratio of total debt to assets by industry by year, with the 49 industries defined as per Fama and French Initial firm leverage (Initial_TDA) is the first non-missing value of Leverage Insider holdings (Hold_Insider) is the total percentage of shares owned by insiders, as per Execucomp

Amihud's Illiquidity is the monthly ratio of absolute stock return to its dollar volume, averaged over the prior twelve months

"EFWA" Market-to-Book is defined as per Baker and Wurgler (2002) as:

$$
\sum_{s=0}^{t-1} \frac{e_{s}+d_{s}}{\sum_{r=0}^{t-1}\left(e_{r}+d_{r}\right)} *(M k t B k)_{s},
$$

where summations begin at either the IPO year or the first year of Compustat data, and $e$ and $d$ denote net equity (SSTK-PRSTKC) and net debt (DLTIS-DLTR+DLCCH) issues

Equity issuance (\% Change Equity) is the ratio of the split-adjusted change in shares outstanding $\left(\mathrm{CSHO}_{t}-\mathrm{CSHO}_{t-1}{ }^{*}\left(\mathrm{AJEX}_{t-1} / \mathrm{AJEX}_{t}\right)\right)$ times the split-adjusted average stock price (PRCC_F $\left.\mathrm{F}_{t}+\mathrm{PRCC}_{-} \mathrm{F}_{t-1} *\left(\mathrm{AJEX}_{t} / \mathrm{AJEX}_{t-1}\right)\right)$ to end of year $t-1$ assets (AT) 
Equity issuer (Equity Issue) is a dummy variable taking the value of one if \% Change Equity > $1.0 \%$, and zero otherwise

Equity Repurchaser (Equity Repo) is a dummy variable taking the value of one if \% Change Equity $<-1.0 \%$, and zero otherwise

Debt issuance (\% Change Debt) is ratio of the change in total debt (DLTT+DLC) from year $t$ 1 to year $t$ to end of year $t-1$ assets (AT)

Net debt issuance (\% Change Net Debt) is the \% Change Debt - \% Change Equity

Net debt issuer (Net Debt Issue) is a dummy variable taking the value of one if \% Change Net Debt $>0$, and zero otherwise

Beta (Beta) is the annual CAPM beta of each firm, as reported in CRSP

Past abnormal return (AdjRet) is each firm's annual return adjusted by the CAPM return using the firm's beta, the 10-year Treasury bond yield, and the realized return on the S\&P 500 index 


\section{REFERENCES}

Admati, Anat R., and Paul Pfleiderer, 2009, The 'Wall Street Walk' and Shareholder Activism: Exit as a Form of Voice, Review of Financial Studies 22, 2445-2485.

Aghion, Philippe, John Van Reenen, and Luigi Zingales, 2009, Innovation and Institutional Ownership, NBER Working Paper Series 14769.

Allen, Franklin, Antonio E. Bernardo, and Ivo Welch, 2000, A Theory of Dividends Based on Tax Clienteles, Journal of Finance 55, 2499-2536.

Alti, Aydogan, and Johan Sulaeman, 2012, When Do High Stock Returns Trigger Equity Issues?, Journal of Financial Economics 103, 61-87.

Amihud, Yakov, 2002, Illiquidity and stock returns: cross-section and time-series effects, Journal of Financial Markets 5, 31-56.

Arellano, Manuel, and Stephen Bond, 1991, Some Tests of Specification for Panel Data: Monte Carlo Evidence and an Application to Employment Equations, Review of Economic Studies 58, 277297.

Baker, Malcolm, and Jeffrey Wurgler, 2002, Market Timing and Capital Structure, Journal of Finance $57,1-32$.

Bennett, James A., Richard W. Sias, and Laura T. Starks, 2003, Greener Pastures and the Impact of Dynamic Institutional Preferences, Review of Financial Studies 16, 1203-1238.

Bhargava, Alok, L. Franzini and Wiji Narendranathan, 1982, Serial Correlation and the Fixed Effects Model, Review of Economic Studies 49, 533-549.

Brav, Alon, John R. Graham, Campbell R. Harvey, and Roni Michaely, 2005, Payout policy in the 21st century, Journal of Financial Economics 77, 483-527.

Bushee, Brian J., and Theodore H. Goodman, 2007, Which Institutional Investors Trade Based on Private Information About Earnings and Returns?, Journal of Accounting Research 45, 289321.

Byoun, Soku, 2008, How and When Do Firms Adjust Their Capital Structures toward Targets?, Journal of Finance 63, 3069-3096.

Chang, Xin, Yangyang Chen, and Sudipto Dasgupta, 2011, Institutional Investor Horizons, Information Environment, and Financing, Working Paper, http://ssrn.com/abstract=2022173.

Chang, Xin, Sudipto Dasgupta, and Gilles Hilary, 2006, Analyst Coverage and Financing Decisions, Journal of Finance 61, 3009-3048.

Chen, Xia, Jarrad Harford, and Kai Li, 2007, Monitoring: Which Institutions Matter?, Journal of Financial Economics 86, 279-305.

Cremers, K. J. Martijn, Vinay B. Nair, and Chenyang Wei, 2007, Governance Mechanisms and Bond Prices, Review of Financial Studies 20, 1359-1388.

Cronqvist, Henrik, and Rüdiger Fahlenbrach, 2009, Large Shareholders and Corporate Policies, Review of Financial Studies 22, 3941 -3976.

Datta, Sudip, Mai Iskandar-Datta, and Katrik Raman, Managerial Stock Ownership and the Maturity Structure of Corporate Debt, Journal of Finance 60, 2333-2350.

Del Guercio, Diane. 1996, The distorting effect of the prudent-man laws on institutional equity investments, Journal of Financial Economics 40, 31-62.

Desai, Mihir A., and Li Jin, 2011, Institutional tax clienteles and payout policy, Journal of Financial Economics 100, 68-84.

Diamond, Douglas W., and Z He, 2011, A Theory of Debt Maturity: The Long and Short of Debt Overhang, Working Paper, http://ssrn.com/paper=1539650.

Edmans, Alex, 2009, Blockholder Trading, Market Efficiency, and Managerial Myopia, Journal of Finance $64,2481-2513$. 
Edmans, Alex, Itay Goldstein, and Wei Jiang, 2011, The Real Effects of Financial Markets: The Impact of Prices on Takeovers (June 6, 2011). AFA 2009 San Francisco Meetings Paper; Journal of Finance, Forthcoming. Available at SSRN: http://ssrn.com/abstract=1102201.

Eisfeldt, Andrea L., and Adriano A. Rampini, 2009, Leasing, Ability to Repossess, and Debt Capacity, Review of Financial Studies 22, 1621 -1657.

Falkenstein, Eric G, 1996, Preferences for Stock Characteristics as Revealed by Mutual Fund Portfolio Holdings, Journal of Finance 51, 111-135.

Faulkender, Michael, Mark J. Flannery, Kristine Watson Hankins, and Jason M. Smith, 2012, Cash Flows and Leverage Adjustments, Journal of Financial Economics 103, 632-646.

Fama, Eugene F., and Kenneth R. French, 2005, Financing decisions: who issues stock?, Journal of Financial Economics 76, 549-582.

Fama, Eugene F., and James D. MacBeth, 1973, Risk, return, and equilibrium: Empirical tests, Journal of Political Economy 81, 607-636.

Fenn, Scott, and Bradley Robinson, 2009, Proxy Voting by Exchange-Traded Funds: An Analysis of ETF Voting Policies, Practices, and Patterns, PROXY Governance Inc. for the IRRC Institute for Corporate Responsibility.

Ferreira, Miguel A., and Pedro Matos, 2008, The colors of investors' money: The role of institutional investors around the world, Journal of Financial Economics 88, 499-533.

Frank, Murray Z., and Vidhan K. Goyal, 2009, Capital Structure Decisions: Which Factors Are Reliably Important?, Financial Management 38, 1-37.

Franzen, Laurel, Kimberly Rodgers Cornaggia, and Timothy T. Simin, 2009, Capital Structure and the Changing Role of Off-Balance-Sheet Lease Financing, Working Paper, http://ssrn.com/ abstract $=1452971$.

Gao, Pengjie and Dong Lou, 2011, Cross-Market Timing in Security Issuance, AFA 2012 Chicago Meetings Paper, Available at SSRN: http://ssrn.com/abstract=1787187

Gaspar, José-Miguel, Massimo Massa, and Pedro Matos, 2005, Shareholder investment horizons and the market for corporate control, Journal of Financial Economics 76, 135-165.

Gillan, Stuart L., and Laura T. Starks, 2000, Corporate governance proposals and shareholder activism: the role of institutional investors, Journal of Financial Economics 57, 275-305.

-_- 2007, The Evolution of Shareholder Activism in the United States, Journal of Applied Corporate Finance 19, 55-73.

Gomes, Armando, 2000, Going Public without Governance: Managerial Reputation Effects, Journal of Finance 55, 615-646.

Gompers, Paul A., Joy Ishii, and Andrew Metrick, 2003, Corporate governance and equity prices, Quarterly Journal of Economics 118, 107-155.

Gompers, Paul A., and Andrew Metrick, 2001, Institutional Investors and Equity Prices, The Quarterly Journal of Economics 116, 229-259.

Graham, John R., Michael L. Lemmon, and James S. Schallheim, 1998, Debt, Leases, Taxes, and the Endogeneity of Corporate Tax Status, Journal of Finance 53, 131-162.

Grinstein, Yaniv, and Roni Michaely, 2005, Institutional Holdings and Payout Policy, Journal of Finance $60,1389-1426$.

Hartzell, Jay C., and Laura T. Starks, 2003, Institutional Investors and Executive Compensation, Journal of Finance 58, 2351-2374.

Heckman, James J., Hidehiko Ichimura, and Petra E. Todd, 1997, Matching as an Econometric Evaluation Estimator: Evidence from Evaluating a Job Training Programme, Review of Economic Studies 64, 605-654.

Hennessy, Christopher A, and Toni M. Whited, 2005, Debt Dynamics, Journal of Finance 60, 11291165.

Holtz-Eakin, Douglas, Whitney Newey, and Harvey S. Rosen, 1988, Estimating Vector Autoregressions with Panel Data, Econometrica 56, 1371-1395. 
Huson, Mark R., Robert Parrino, and Laura T. Starks, 2001, Internal Monitoring Mechanisms and CEO Turnover: A Long-Term Perspective, Journal of Finance 56, 2265-2297.

Iliev, Peter, Karl Lins, Darius Miller, and Lukas Roth, 2012, Shareholder Voting and Corporate Governance Around the World, Working Paper, http://ssrn.com/abstract=1702546.

Jensen, Michael C. 1986, Agency Costs of Free Cash Flow, Corporate Finance, and Takeovers, American Economic Review 76, 323-329.

- - - 1993, The Modern Industrial Revolution, Exit, and the Failure of Internal Control Systems, Journal of Finance 48, 831-880.

Jensen, Michael C., and William H. Meckling, 1976, Theory of the firm: Managerial behavior, agency costs and ownership structure, Journal of Financial Economics 3, 305-360.

Jiang, Wei, Kai Li, and Pei Shao, 2010, When Shareholders Are Creditors: Effects of the Simultaneous Holding of Equity and Debt by Noncommercial-Banking Institutions, Working Paper, http://ssrn.com/abstract $=1619927$.

Kleibergen, Frank, and Richard Paap, 2006, Generalized reduced rank tests using the singular value decomposition, Journal of Econometrics 133, 97-126.

La Porta, Rafael, Florencio Lopez-De-Silanes, Andrei Shleifer, and Robert W. Vishny, 2000, Agency Problems and Dividend Policies around the World, Journal of Finance 55, 1-33.

Lemmon, Michael L., Michael R. Roberts, and Jaime F. Zender, 2008, Back to the Beginning: Persistence and the Cross-Section of Corporate Capital Structure, Journal of Finance 63, 15751608.

Leary, Mark T., and Michael R. Roberts, 2005, Do Firms Rebalance Their Capital Structures?, Journal of Finance 60, 2575-2619.

Ljungqvist, Alexander, Felicia Marston, Laura T. Starks, Kelsey D. Wei, and Hong Yan, 2007, Conflicts of interest in sell-side research and the moderating role of institutional investors, Journal of Financial Economics 85, 420-456.

Levit, Doron, 2012, Soft Shareholder Activism, Working paper, university of Pennsylvania.

Maug, Ernst, 1998, Large Shareholders as Monitors: Is There a Trade-Off between Liquidity and Control?, Journal of Finance 53, 65-98.

McCahery, Joseph A., Zacharias Sautner, and Laura T. Starks, 2010, Behind the Scenes: The Corporate Governance Preferences of Institutional Investors, Working Paper, http://ssrn.com/abstract=1571046.

Morgan, Angela, Annette Poulsen, Jack Wolf, and Tina Yang, 2011, Mutual funds as monitors: evidence from mutual fund voting, Journal of Corporate Finance 17, 914-928.

Myers, Stewart C., 1977, Determinants of corporate borrowing, Journal of Financial Economics 5, 147-175.

Myers, Stewart C., and Nicholas S. Majluf, 1984, Corporate financing and investment decisions when firms have information that investors do not have, Journal of Financial Economics 13, 187221.

Neubert, Albert S., 1985, The Ins and Outs of the S\&P 500, Market Perspectives 3.

Nickell, Stephen, 1981, Biases in Dynamic Models with Fixed Effects, Econometrica 49, 1417-1426.

Ortiz-Molina, Hernan, 2006, Top Management Incentives and the Pricing of Corporate Public Debt, Journal of Financial and Quantitative Analysis 41, 317-340.

Parrino, Robert, Richard W. Sias, and Laura T. Starks, 2003, Voting with their feet: institutional ownership changes around forced CEO turnover, Journal of Financial Economics 68, 3-46.

Pruitt, Stephen W., and K.C. John Wei, 1989, Institutional Ownership and Changes in the S\&P 500, Journal of Finance 44, 509-513.

Rampini, Adriano A., and S. Viswanathan, 2010, Collateral and Capital Structure, Working Paper, http://ssrn.com/abstract=1356940.

Rosenbaum, Paul R., and Donald R. Rubin, 1983, The Central Role of the Propensity Score in Observation Studies for Causal Effects, Biometrika 70, 41-55. 
- - - 1985, Constructing a Control Group Using Multivariate Matched Sampling Methods That Incorporate the Propensity Score, American Statistician 39, 33-38.

Ross, Stephen A., 1977, The Determination of Financial Structure: The Incentive-Signalling Approach, Bell Journal of Economics 8, 23-40.

Shleifer, Andrei, and Robert W. Vishny, 1986, Large Shareholders and Corporate Control, Journal of Political Economy 94, 461-488.

Sias, Richard W., 2004, Institutional Herding, Review of Financial Studies 17, 165-206.

Stock, James, and Motohiro Yogo, 2005, Asymptotic distributions of instrumental variables statistics with many weak instruments, Identification and Inference for Econometric Models: Essays in Honor of Thomas Rothenberg, D.W.K. Andrews and J.H. Stock eds., Cambridge University Press, Cambridge, U.K.

Strebulaev, Ilya A, 2007, Do Tests of Capital Structure Theory Mean What They Say?, Journal of Finance $62,1747-1787$.

Stulz, René M., 1990, Managerial discretion and optimal financing policies, Journal of Financial Economics 26, 3-27.

Viswanath, P. V., 1993, Strategic Considerations, the Pecking Order Hypothesis, and Market Reactions to Equity Financing, Journal of Financial and Quantitative Analysis 28, 213-234.

Zwiebel, Jeffery, 1996, Dynamic Capital Structure under Managerial Entrenchment, American Economic Review 86, 1197-1215. 


\section{Table I \\ Summary Statistics}

This table reports simple means for a number of corporate finance. Market Cap is defined as Institutional Holdings (Hold) is defined as total institutional holdings relative to total shares outstanding. Similarly, Top 5 institutional holdings is the percent of total shares outstanding held by the five largest institutional investors. Leverage (TDA) is defined as total debt scaled by book assets. Log(Assets) (Assets) is the natural logarithm of total assets. Market to Book $(M k t / B k)$ is defined as the market value of assets scaled by the book value of assets. Profitability (Profit) is defined as operating income before depreciation scaled by book assets. Log(Sales) (Sales) is the natural logarithm of total sales. Capital Expenditures (Capex) is defined as capital expenditure scaled by book assets. Intangible Assets (Intang) is defined as intangible assets scaled by book assets. Tangibility (Tang) is defined as the tangible assets (net PP\&E) scaled by book assets. Collateral (Colltrl) is defined as total collateral (the sum of inventory and net property, plant, and equipment) scaled by book assets. The sample consists of all U.S. incorporated firms, excluding financial firms and utilities, with a positive market cap, positive assets, and non-missing total debt. Accounting data is obtained from the Compustat-CRSP merged database, and institutional holdings data is obtained from Thomson-Reuters via 13F SEC filings.

\begin{tabular}{lcccc}
\hline & Full Sample & & \multicolumn{2}{c}{ Subsamples } \\
\cline { 2 - 3 } \cline { 4 - 5 } Variable & 1979 to 2009 & & 1979 to 1994 & 1995 to 2009 \\
\hline Market Cap (\$MM) & $1,757.99$ & & 872.47 & $2,654.70$ \\
Institutional Holdings & 0.29 & 0.19 & 0.40 \\
Institutional Holdings, Top 5 & 0.15 & & 0.11 & 0.20 \\
Leverage & 0.24 & 0.25 & 0.22 \\
Log(Assets) & 5.03 & & 4.68 & 5.38 \\
Market to Book & 1.72 & & 1.57 & 1.89 \\
Profitability & 0.04 & & 0.07 & 0.02 \\
Log(Sales) & 4.95 & & 4.70 & 5.20 \\
Capital Expenditures & 0.07 & 0.08 & 0.06 \\
Intangible Assets & 0.09 & 0.05 & 0.13 \\
Tangibility & 0.29 & 0.32 & 0.25 \\
Collateral & 0.44 & 0.51 & 0.38 \\
Firm Years & 130,202 & 65,510 & 64,692 \\
\hline
\end{tabular}




\section{Table II \\ The Effect of Institutional Holdings on Leverage}

This table reports estimates from panel regressions of leverage on institutional holdings. The dependent variables are measured at the end of fiscal year $t$, and the independent variables, described in Table I and defined in the Appendix, are measured at ( $t-1)$. TDLA is defined as total debt including off-balance-sheet operating leases scaled by (total assets plus off-balance-sheet operating leases). Cap1- Cap5 are annual market cap quintile dummy variables corresponding to the smallest and largest firms, ascending. Industry_TDA is defined as the annual median leverage per Fama-French industry group. Initial_TDA is defined as each firm's first non-missing leverage ratio. Dividend is a dummy variable equal to one if a firm pays a dividend and zero otherwise. All specifications contain an intercept, and the following independent variables, omitted for brevity and defined in the Appendix: Intang, Payout, Unique, Losses, and ChgAssets. Columns 3 and 6 also contain dummy variables Cap1 - Cap4. Column 4 includes annual stock return adjusted for the predicted CAPM return. Column 5 includes insider holdings (from ExecuComp) scaled by total shares outstanding, with and without a fixed effect, respectively, and reflect data for S\&P 1500 firms from 1992 to 2009. In column 6, Analyst Coverage is calculated using data from the I/B/E/S Historical Summary File as the maximum number of analysts who make annual earnings forecasts in any month during the twelve months prior to fiscal year end, while assuming that firms not covered by I/B/E/S have no analyst coverage. In column 7 independent variables are normalized by (assets + OBS operating leases) rather than (assets), as our measure for leverage in this column, TDLA, includes OBS operating leases. The data consist of all U.S. incorporated firms with CRSP, Compustat, and institutional holdings data between 1979 and 2009 (with the exception of columns 4 and 5), excluding financial firms and utilities. Institutional holdings data is obtained from Thomson-Reuters via $13 \mathrm{~F}$ SEC filings. ${ }^{* * *}, * *$, and $*$ represent statistical significance at the $1 \%, 5 \%$, and $10 \%$ level, respectively, and standard errors, reported in parentheses, are clustered at the firm level. 
Table II - Continued

\begin{tabular}{|c|c|c|c|c|c|c|c|}
\hline \multicolumn{8}{|c|}{ Leverage in levels } \\
\hline & $\begin{array}{c}(1) \\
T D A(t)\end{array}$ & $\begin{array}{c}(2) \\
T D A(t)\end{array}$ & $\begin{array}{c}(3) \\
T D A(t)\end{array}$ & $\begin{array}{c}(4) \\
T D A(t)\end{array}$ & $\begin{array}{c}(5) \\
T D A(t)\end{array}$ & $\begin{array}{c}(6) \\
T D A(t)\end{array}$ & $\begin{array}{c}(7) \\
T D L A(t)\end{array}$ \\
\hline $\operatorname{Hold}(t-1)$ & $\begin{array}{c}-0.100^{* * *} \\
(0.0069)\end{array}$ & $\begin{array}{c}-0.068^{* * *} \\
(0.0080)\end{array}$ & & $\begin{array}{c}-0.070^{* * *} \\
(0.0085)\end{array}$ & $\begin{array}{c}-0.044^{* * *} \\
(0.0158)\end{array}$ & $\begin{array}{c}-0.057^{* * *} \\
(0.0079)\end{array}$ & \\
\hline Hold $x$ Cap $1(t-1)$ & & & $\begin{array}{c}-0.108^{* * *} \\
(0.0184)\end{array}$ & & & & $\begin{array}{c}-0.085^{* * *} \\
(0.0191)\end{array}$ \\
\hline Hold $x$ Cap $2(t-1)$ & & & $\begin{array}{c}-0.082^{* * * *} \\
(0.0120)\end{array}$ & & & & $\begin{array}{c}-0.073^{* * *} \\
(0.0123)\end{array}$ \\
\hline Hold $x$ Cap $3(t-1)$ & & & $\begin{array}{c}-0.060^{* * *} \\
(0.0099)\end{array}$ & & & & $\begin{array}{c}-0.050^{* * *} \\
(0.0099)\end{array}$ \\
\hline Hold $x$ Cap $4(t-1)$ & & & $\begin{array}{c}-0.040^{* * *} \\
(0.0094)\end{array}$ & & & & $\begin{array}{c}-0.035^{* * *} \\
(0.0097)\end{array}$ \\
\hline Hold $x$ Cap5 $(t-1)$ & & & $\begin{array}{c}-0.020^{*} \\
(0.0105)\end{array}$ & & & & $\begin{array}{c}-0.019 * \\
(0.0106)\end{array}$ \\
\hline Adjusted Ret. $(t-1)$ & & & & $\begin{array}{c}-0.012^{* * *} \\
(0.0014)\end{array}$ & & & \\
\hline Insider Hold. $(t-1)$ & & & & & $\begin{array}{c}0.009 \\
(0.0378)\end{array}$ & & \\
\hline Analyst Cov. $(t-1)$ & & & & & & $\begin{array}{c}-0.003^{* * *} \\
(0.0004)\end{array}$ & \\
\hline $\operatorname{Assets}(t-1)$ & $\begin{array}{l}0.022^{* * *} \\
(0.0011)\end{array}$ & $\begin{array}{c}0.031^{* * *} \\
(0.0027)\end{array}$ & $\begin{array}{c}0.053^{* * *} \\
(0.0030)\end{array}$ & $\begin{array}{l}0.030^{* * *} \\
(0.0029)\end{array}$ & $\begin{array}{l}0.020^{* * *} \\
(0.0065)\end{array}$ & $\begin{array}{l}0.037^{* * *} \\
(0.0028)\end{array}$ & $\begin{array}{l}0.039 \text { *** } \\
(0.0031)\end{array}$ \\
\hline $\operatorname{Profit}(t-1)$ & $\begin{array}{c}-0.138^{* * *} \\
(0.0079)\end{array}$ & $\begin{array}{c}-0.120^{* * *} \\
(0.0091)\end{array}$ & $\begin{array}{c}-0.103^{* * *} \\
(0.0091)\end{array}$ & $\begin{array}{c}-0.109^{* * *} \\
(0.0101)\end{array}$ & $\begin{array}{c}-0.203^{* * *} \\
(0.0465)\end{array}$ & $\begin{array}{c}-0.123^{* * *} \\
(0.0091)\end{array}$ & $\begin{array}{c}-0.106^{* * *} \\
(0.0113)\end{array}$ \\
\hline$M k t / B k(t-1)$ & $\begin{array}{c}-0.001 \\
(0.0008)\end{array}$ & $\begin{array}{c}0.001 \\
(0.0009)\end{array}$ & $\begin{array}{c}0.009 * * * \\
(0.0009)\end{array}$ & $\begin{array}{c}0.003^{* *} \\
(0.0011)\end{array}$ & $\begin{array}{c}0.000 \\
(0.0032)\end{array}$ & $\begin{array}{c}0.001 \\
(0.0009)\end{array}$ & $\begin{array}{l}0.007^{* * *} \\
(0.0012)\end{array}$ \\
\hline Industry_TDA $(t-1)$ & $\begin{array}{l}0.282^{* * *} \\
(0.0189)\end{array}$ & $\begin{array}{c}0.315^{* * *} \\
(0.0336)\end{array}$ & $\begin{array}{c}0.286^{* * *} \\
(0.0325)\end{array}$ & $\begin{array}{l}0.304^{* * *} \\
(0.0358)\end{array}$ & $\begin{array}{l}0.288^{* * *} \\
(0.0652)\end{array}$ & $\begin{array}{l}0.311^{* * *} \\
(0.0334)\end{array}$ & $\begin{array}{l}0.226^{* * *} \\
(0.0356)\end{array}$ \\
\hline Initial_TDA $(t-1)$ & $\begin{array}{l}0.346^{* * *} \\
(0.0101)\end{array}$ & & & & & & \\
\hline Dividend $(t-1)$ & $\begin{array}{c}-0.060^{* * *} \\
(0.0034)\end{array}$ & $\begin{array}{c}-0.024^{* * *} \\
(0.0038)\end{array}$ & $\begin{array}{c}-0.018^{* * *} \\
(0.0037)\end{array}$ & $\begin{array}{c}-0.023^{* * *} \\
(0.0041)\end{array}$ & $\begin{array}{c}-0.012 \\
(0.0080)\end{array}$ & $\begin{array}{c}-0.023^{* * *} \\
(0.0038)\end{array}$ & $\begin{array}{c}-0.013^{* * *} \\
(0.0039)\end{array}$ \\
\hline $\operatorname{Capex}(t-1)$ & $\begin{array}{c}0.035^{*} \\
(0.0177)\end{array}$ & $\begin{array}{c}0.021 \\
(0.0154)\end{array}$ & $\begin{array}{c}0.062^{* * *} \\
(0.0152)\end{array}$ & $\begin{array}{c}0.022 \\
(0.0170)\end{array}$ & $\begin{array}{c}0.028 \\
(0.0481)\end{array}$ & $\begin{array}{c}0.022 \\
(0.0153)\end{array}$ & $\begin{array}{c}-0.010 \\
(0.0202)\end{array}$ \\
\hline $\operatorname{Tang}(t-1)$ & $\begin{array}{c}0.065^{* * *} \\
(0.0119)\end{array}$ & $\begin{array}{c}0.094^{* * *} \\
(0.0225)\end{array}$ & $\begin{array}{c}0.079 * * * \\
(0.0219)\end{array}$ & $\begin{array}{l}0.091^{* * *} \\
(0.0245)\end{array}$ & $\begin{array}{c}-0.004 \\
(0.0773)\end{array}$ & $\begin{array}{l}0.099 * * * \\
(0.0224)\end{array}$ & $\begin{array}{l}0.295^{* * *} \\
(0.0196)\end{array}$ \\
\hline Observations & 88,444 & 88,444 & 88,444 & 77,250 & 15,795 & 88,444 & 66,285 \\
\hline Firm Fixed Effect & No & Yes & Yes & Yes & Yes & Yes & Yes \\
\hline Year Fixed Effect & Yes & Yes & Yes & Yes & Yes & Yes & Yes \\
\hline Adj. $R$-squared & 0.323 & 0.639 & 0.646 & 0.648 & 0.699 & 0.640 & 0.690 \\
\hline
\end{tabular}




\section{Table III}

\section{The Effect of Changes in Institutional Holdings on Changes in Leverage}

This table reports estimates from panel regressions of changes in leverage on changes in institutional holdings. The first-differenced dependent variables are calculated as $Y_{t}-Y_{t-1}$, and the first-differenced independent variables, described in Table I and defined in the Appendix, are calculated as $\boldsymbol{X}_{t-1}-\boldsymbol{X}_{t-2}$. In column 2, independent variables are normalized by (assets + operating leases) rather than (assets), as the measure of leverage used includes leases. The data consist of all U.S. incorporated firms with CRSP, Compustat, and institutional holdings data between 1979 and 2009, excluding financial firms and utilities. Institutional holdings data is obtained from Thomson-Reuters via 13F SEC filings. ${ }^{* * *}, * *$, and ${ }^{*}$ represent statistical significance at the $1 \%, 5 \%$, and $10 \%$ level, respectively, and standard errors, reported in parentheses, are clustered at the firm level.

\begin{tabular}{|c|c|c|}
\hline & $\begin{array}{c}(1) \\
\Delta T D A(t)\end{array}$ & $\begin{array}{c}(2) \\
\Delta T D L A(t)\end{array}$ \\
\hline$\Delta \operatorname{Hold}(t-1)$ & $\begin{array}{c}-0.014^{* * *} \\
(0.0047)\end{array}$ & $\begin{array}{l}-0.022^{* * *} \\
(0.0047)\end{array}$ \\
\hline$\Delta T D A(t-1)$ & $\begin{array}{c}-0.153^{* * *} \\
(0.0070)\end{array}$ & \\
\hline$\Delta T D L A(t-1)$ & & $\begin{array}{l}-0.143^{* * *} \\
(0.0079)\end{array}$ \\
\hline$\Delta \operatorname{Assets}(t-1)$ & $\begin{array}{c}0.026^{* * *} \\
(0.0024)\end{array}$ & $\begin{array}{l}0.027^{* * *} \\
(0.0025)\end{array}$ \\
\hline$\Delta \operatorname{Profit}(t-1)$ & $\begin{array}{c}-0.045^{* * *} \\
(0.0064)\end{array}$ & $\begin{array}{c}-0.039 * * * \\
(0.0083)\end{array}$ \\
\hline$\Delta M k t / B k(t-1)$ & $\begin{array}{l}-0.002^{* * *} \\
(0.0006)\end{array}$ & $\begin{array}{l}-0.004^{* * *} \\
(0.0007)\end{array}$ \\
\hline$\Delta$ Industry_TDA $(t-1)$ & $\begin{array}{l}0.065^{* * *} \\
(0.0204)\end{array}$ & $\begin{array}{l}0.069^{* * *} \\
(0.0229)\end{array}$ \\
\hline$\Delta$ Dividend $(t-1)$ & $\begin{array}{c}0.002 \\
(0.0021)\end{array}$ & $\begin{array}{c}0.003 \\
(0.0022)\end{array}$ \\
\hline$\Delta \operatorname{Capex}(t-1)$ & $\begin{array}{c}0.059^{* * *} \\
(0.0111)\end{array}$ & $\begin{array}{c}0.036^{* *} \\
(0.0149)\end{array}$ \\
\hline$\Delta \operatorname{Tang}(t-1)$ & $\begin{array}{c}0.020 \\
(0.0172)\end{array}$ & $\begin{array}{l}0.051^{* * *} \\
(0.0165)\end{array}$ \\
\hline$\Delta \operatorname{Colltrl}(t-1)$ & $\begin{array}{l}0.058^{* * *} \\
(0.0133)\end{array}$ & $\begin{array}{l}0.045^{* * *} \\
(0.0134)\end{array}$ \\
\hline$\Delta \operatorname{Intang}(t-1)$ & $\begin{array}{c}0.021^{* *} \\
(0.0102)\end{array}$ & $\begin{array}{c}0.008 \\
(0.0104)\end{array}$ \\
\hline$\Delta$ Payout $(t-1)$ & $\begin{array}{l}0.033^{* * *} \\
(0.0103)\end{array}$ & $\begin{array}{l}0.039 * * * \\
(0.0113)\end{array}$ \\
\hline Observations & 72,208 & 52,127 \\
\hline Year Fixed Effect & Yes & Yes \\
\hline Adj. $R$-squared & 0.033 & 0.036 \\
\hline
\end{tabular}




\section{Table IV \\ The Effect of Leverage on Institutional Holdings - Levels and Differences}

This table reports estimates from panel regressions of changes in institutional holdings on changes in leverage. In Panel A, the dependent variables are measured at the end of fiscal year $t$, and the independent variables are measured at $(t-1)$. In Panel B, the first-differenced dependent variable is calculated as $Y_{t}-Y_{t-1}$, and the first-differenced independent variables are calculated as $\boldsymbol{X}_{t-1}-\boldsymbol{X}_{t-2}$. Payout is defined as annual dividends plus repurchases scaled by book assets. Adjusted Ret. is defined as a firms' annual return adjusted by the CAPM return. Beta is a firm's annual CAPM beta. TDA, TDLA, Sales, Dividend, and Mkt/Bk are described in Table I, and all variables are defined in the Appendix. The data consist of all U.S. incorporated firms with CRSP, Compustat, and institutional holdings data between 1979 and 2009, excluding financial firms and utilities. Institutional holdings data is obtained from Thomson-Reuters via 13F SEC filings. ${ }^{* * *}, * *$, and * represent statistical significance at the $1 \%, 5 \%$, and $10 \%$ level, respectively, and standard errors, reported in parentheses, are clustered at the firm level.

\begin{tabular}{|c|c|c|c|c|}
\hline \multicolumn{3}{|c|}{ Panel A - Inst. Holdings in Levels } & \multicolumn{2}{|c|}{ Panel B - Inst. Holdings in Differences } \\
\hline & $\begin{array}{c}(1) \\
\text { Hold }(t)\end{array}$ & $\begin{array}{c}(2) \\
\operatorname{Hold}(t)\end{array}$ & & $\begin{array}{c}(1) \\
\Delta \operatorname{Hold}(t) \\
\end{array}$ \\
\hline$T D A(t-1)$ & $\begin{array}{c}-0.123^{* * *} \\
(0.0080)\end{array}$ & $\begin{array}{c}-0.087^{* * *} \\
(0.0079)\end{array}$ & $\Delta T D A(t-1)$ & $\begin{array}{c}-0.037^{* * *} \\
(0.0042)\end{array}$ \\
\hline & & & $\Delta \operatorname{Hold}(t-1)$ & $\begin{array}{c}-0.125^{* * *} \\
(0.0071)\end{array}$ \\
\hline$M k t / B k(t-1)$ & $\begin{array}{l}0.016^{* * *} \\
(0.0010)\end{array}$ & $\begin{array}{l}0.011^{* * *} \\
(0.0008)\end{array}$ & $\Delta M k t / B k(t-1)$ & $\begin{array}{l}0.003^{* * *} \\
(0.0004)\end{array}$ \\
\hline Sales $(t-1)$ & $\begin{array}{l}0.067^{* * *} \\
(0.0011)\end{array}$ & $\begin{array}{l}0.039^{* * *} \\
(0.0019)\end{array}$ & $\Delta$ Sales $(t-1)$ & $\begin{array}{c}0.007^{* * *} \\
(0.0009)\end{array}$ \\
\hline Dividend $(t-1)$ & $\begin{array}{c}0.010^{* *} \\
(0.0047)\end{array}$ & $\begin{array}{c}0.011^{* *} \\
(0.0047)\end{array}$ & $\Delta$ Dividend $(t-1)$ & $\begin{array}{c}0.004^{*} \\
(0.0021)\end{array}$ \\
\hline Payout $(t-1)$ & $\begin{array}{l}0.192 * * * \\
(0.0361)\end{array}$ & $\begin{array}{c}0.049 * * \\
(0.0217)\end{array}$ & $\Delta$ Payout $(t-1)$ & $\begin{array}{c}-0.005 \\
(0.0096)\end{array}$ \\
\hline $\operatorname{Beta}(t-1)$ & $\begin{array}{c}0.049^{* * *} \\
(0.0020)\end{array}$ & $\begin{array}{l}0.013^{* * *} \\
(0.0013)\end{array}$ & $\Delta \operatorname{Beta}(t-1)$ & $\begin{array}{c}-0.001 \\
(0.0006)\end{array}$ \\
\hline Adjusted Ret. $(t-1)$ & $\begin{array}{l}0.006^{* * *} \\
(0.0004)\end{array}$ & $\begin{array}{l}0.002^{* * *} \\
(0.0003)\end{array}$ & $\Delta$ Adjusted $\operatorname{Ret}(t-1)$ & $\begin{array}{l}0.001^{* * *} \\
(0.0001)\end{array}$ \\
\hline Observations & 84,764 & 84,764 & Observations & 71,093 \\
\hline Firm Fixed Effect & No & Yes & Firm Fixed Effect & No \\
\hline Year Fixed Effect & Yes & Yes & Year Fixed Effect & Yes \\
\hline Adj. $R$-squared & 0.521 & 0.816 & Adj. $R$-squared & 0.036 \\
\hline
\end{tabular}




\section{Table V}

\section{Arellano-Bond - Institutional Holdings and Leverage}

This table reports estimates from Arellano-Bond autoregressions of leverage on institutional holdings (Panel $A$ ), and institutional holdings on leverage (Panel B). The dependent variables are measured at the end of year $t$, and the independent variables, described in Tables I and IV and defined in the Appendix, are measured as of time ( $t$-1). In Panel A, we also control for Colltrl, Intang, Payout, Unique, and Losses. In both panels, internal instruments begin with lag 3. Accordingly, the Arellano-Bond AR(3) test is presented in first differences to rule out second order serial correlation between the first-differenced error term at time $t$ and the level at time $t$-3. The null hypothesis is no serial correlation. The data consist of all U.S. incorporated firms with CRSP, Compustat, and institutional holdings data for a minimum of four consecutive years between 1979 and 2009, excluding financial firms and utilities. Institutional holdings data is obtained from Thomson-Reuters via $13 \mathrm{~F}$ SEC filings. ${ }^{* * *}, * *$, and $*$ represent statistical significance at the $1 \%, 5 \%$, and $10 \%$ level, respectively, and standard errors, reported in parentheses, are robust to any pattern of heteroskedasticity and autocorrelation within panels.

\begin{tabular}{|c|c|c|c|c|c|}
\hline \multicolumn{3}{|c|}{ Panel A - Leverage Regression } & \multicolumn{3}{|c|}{ Panel B - Institutional Holdings Regression } \\
\hline & $\begin{array}{c}(1) \\
T D A(t)\end{array}$ & $\begin{array}{c}(2) \\
T D A(t) \\
\end{array}$ & & $\begin{array}{c}(1) \\
\operatorname{Hold}(t)\end{array}$ & $\begin{array}{c}(2) \\
\text { Hold5 }(t)\end{array}$ \\
\hline $\operatorname{Hold}(t-1)$ & $\begin{array}{c}-0.148^{* * *} \\
(0.0260)\end{array}$ & & $\operatorname{Hold}(t-1)$ & $\begin{array}{l}0.924^{* * *} \\
(0.0335)\end{array}$ & \\
\hline $\operatorname{Hold} 5(t-1)$ & & $\begin{array}{c}-0.183^{* * *} \\
(0.0363)\end{array}$ & Hold5 $(t-1)$ & & $\begin{array}{l}0.872^{* * *} \\
(0.0221)\end{array}$ \\
\hline$T D A(t-1)$ & $\begin{array}{l}0.635^{* * *} \\
(0.0222)\end{array}$ & $\begin{array}{l}0.650^{* * *} \\
(0.0258)\end{array}$ & $T D A(t-1)$ & $\begin{array}{c}0.012 \\
(0.0174)\end{array}$ & $\begin{array}{c}0.003 \\
(0.0107)\end{array}$ \\
\hline $\operatorname{Assets}(t-1)$ & $\begin{array}{l}0.021^{* * *} \\
(0.0027)\end{array}$ & $\begin{array}{l}0.015^{* * *} \\
(0.0018)\end{array}$ & $M k t / B k(t-1)$ & $\begin{array}{c}-0.007^{* * *} \\
(0.0008)\end{array}$ & $\begin{array}{c}0.000 \\
(0.0004)\end{array}$ \\
\hline $\operatorname{Profit}(t-1)$ & $\begin{array}{l}-0.031^{* * *} \\
(0.0072)\end{array}$ & $\begin{array}{c}0.055 \\
(0.0580)\end{array}$ & Sales $(t-1)$ & $\begin{array}{c}-0.011^{* * *} \\
(0.0013)\end{array}$ & $\begin{array}{c}0.000 \\
(0.0008)\end{array}$ \\
\hline$M k t / B k(t-1)$ & $\begin{array}{c}0.001 \\
(0.0007)\end{array}$ & $\begin{array}{c}0.000 \\
(0.0009)\end{array}$ & Dividend $(t-1)$ & $\begin{array}{c}-0.005 \\
(0.0031)\end{array}$ & $\begin{array}{c}0.001 \\
(0.0020)\end{array}$ \\
\hline Industry_TDA $(t-1)$ & $\begin{array}{l}0.068^{* * *} \\
(0.0190)\end{array}$ & $\begin{array}{l}0.072^{* * *} \\
(0.0187)\end{array}$ & Payout $(t-1)$ & $\begin{array}{c}-0.020 \\
(0.0175)\end{array}$ & $\begin{array}{c}-0.031^{* * *} \\
(0.0104)\end{array}$ \\
\hline Dividend $(t-1)$ & $\begin{array}{c}0.004^{*} \\
(0.0022)\end{array}$ & $\begin{array}{c}0.004 \\
(0.0076)\end{array}$ & $\operatorname{Beta}(t-1)$ & $\begin{array}{c}-0.006^{* * *} \\
(0.0010)\end{array}$ & $\begin{array}{c}-0.001 \\
(0.0006)\end{array}$ \\
\hline Capex $(t-1)$ & $\begin{array}{l}0.127^{* * *} \\
(0.0114)\end{array}$ & $\begin{array}{l}0.117^{* * *} \\
(0.0119)\end{array}$ & Adjusted Ret. $(t-1)$ & $\begin{array}{c}0.000^{*} \\
(0.0002)\end{array}$ & $\begin{array}{c}0.000 \\
(0.0002)\end{array}$ \\
\hline $\operatorname{Tang}(t-1)$ & $\begin{array}{c}-0.008 \\
(0.0134)\end{array}$ & $\begin{array}{c}-0.012 \\
(0.0135)\end{array}$ & & & \\
\hline Observations & 71,493 & 71,493 & Observations & 71,096 & 71,093 \\
\hline Number of firms & 9,244 & 9,244 & Number of firms & 9,396 & 9,395 \\
\hline $\mathrm{AR}(3) \operatorname{Pr}>\mathrm{z}$ & 0.844 & 0.985 & $\operatorname{AR}(3) \operatorname{Pr}>z$ & 0.603 & 0.486 \\
\hline Hansen $J$-statistic & 75.16 & 52.28 & Hansen $J$-statistic & 16.24 & 9.239 \\
\hline Hansen p-value & 0.030 & 0.463 & Hansen p-value & 0.181 & 0.682 \\
\hline
\end{tabular}




\section{Table VI \\ Instrumental Variables - The Effect of Institutional Holdings on Leverage}

This table reports estimates from linear two-stage least squares panel regressions of leverage on institutional holdings. The dependent variable, TDA, is measured at the end of fiscal year $t$, and the independent variables, described in Table I and II and defined in the Appendix, are measured as of time $(t-1)$. The instrument for Hold in column 1, MFFlow, is the hypothetical annual change in mutual fund holdings implied by previously disclosed holdings and quarterly mutual fund outflows $\geq 5 \%$ of total fund assets. All specifications contain an intercept, and the following independent variables omitted for brevity: Unique, Losses and ChgAssets. The data consist of all U.S. incorporated firms with CRSP, Compustat, and institutional holdings data between 1980 and 2007 (due to the availability of MFFlow data), excluding financial firms and utilities. Institutional holdings data is obtained from Thomson-Reuters via 13F SEC filings, while MFFlow data is obtained from Alex Edmans's website. ${ }^{* * *},{ }^{* *}$, and ${ }^{*}$ represent statistical significance at the $1 \%, 5 \%$, and $10 \%$ level, respectively, and standard errors, reported in parentheses, are clustered at the firm level.

(1)

2SLS: $T D A(t)$

\section{Instrument}

$\operatorname{Hold}(t-1)$

$\operatorname{Assets}(t-1)$

$\operatorname{Profit}(t-1)$

$M k t / B k(t-1)$

Industry_TDA $(t-1)$

Initial_TDA $(t-1)$

Dividend $(t-1)$

Capex $(t-1)$

$\operatorname{Tang}(t-1)$

$\operatorname{Colltrl}(t-1)$

$\operatorname{Intang}(t-1)$

Payout $(t-1)$

First Stage Adj. $R$-squared

First Stage F-Statistic

Observations

Year Fixed Effect

Adj. $R$-squared
MFFlow

$-0.292^{* * *}$

(0.0378)

$0.037^{* * *}$

(0.0033)

$-0.123^{* * *}$

(0.0086)

0.002

(0.0010)

$0.258^{* * *}$

(0.0204)

$0.332^{* * *}$

(0.0106)

$-0.061^{* * *}$

(0.0036)

$0.061^{* * *}$

(0.0192)

$0.051^{* * *}$

(0.0125)

$0.158^{* * *}$

(0.0104)

$0.301^{* * *}$

(0.0121)

$-0.017$

(0.0268)

0.548

354.63

80,611

Yes

0.291 


\section{Table VII \\ S\&P 500 Inclusion - The Effect of a Shock to Institutional Holdings on Leverage}

This table reports leverage difference-in-difference tests surrounding addition to the S\&P 500 Index. The treatment group consists of a sample of U.S. incorporated firms that were added to the S\&P 500 between the third quarter of 1979 and 2008, while the control group consists of a propensity score matched sample of U.S. incorporated firms. Financial firms and utilities are excluded. Panel A presents summary statistics for the two groups of firms in the quarter before index addition. In Panel B we conduct a difference-in-difference paired t-test comparing the mean difference in leverage $(T D A)$ in the quarter before addition to the mean difference four quarters after addition. Panel $\mathrm{C}$ reports estimates from a panel regression of leverage on a treatment/control dummy variable (Treatment $=1$ if in the treatment group, 0 otherwise), a Pre/Post S\&P 500 addition dummy variable (Post $=1$ if after addition, 0 otherwise), their interaction Treatment ${ }^{*}$ Post, as well as other control variables. The dependent variable, TDA, is measured at the end of quarter $t$. To mitigate concerns over market timing we control for lagged and contemporaneous CAPM-adjusted return, as well as lagged and contemporaneous illiquidity (Amihud (2002)). Furthermore, we control for the independent variables used in Table II column 1. These variables, described in Table I and defined in the Appendix, are measured as of quarter $(t-1)$. To isolate the effect of the shock in institutional holdings stemming from S\&P 500 inclusion, we restrict our sample to 9 quarters per firm: the period 4 quarters before inclusion to 4 quarters after inclusion. Institutional holdings data is obtained from Thomson-Reuters via 13F SEC filings. ${ }^{* * *}$, **, and

* represent statistical significance at the $1 \%, 5 \%$, and $10 \%$ level, respectively, and standard errors, reported in parentheses, are clustered at the firm level.

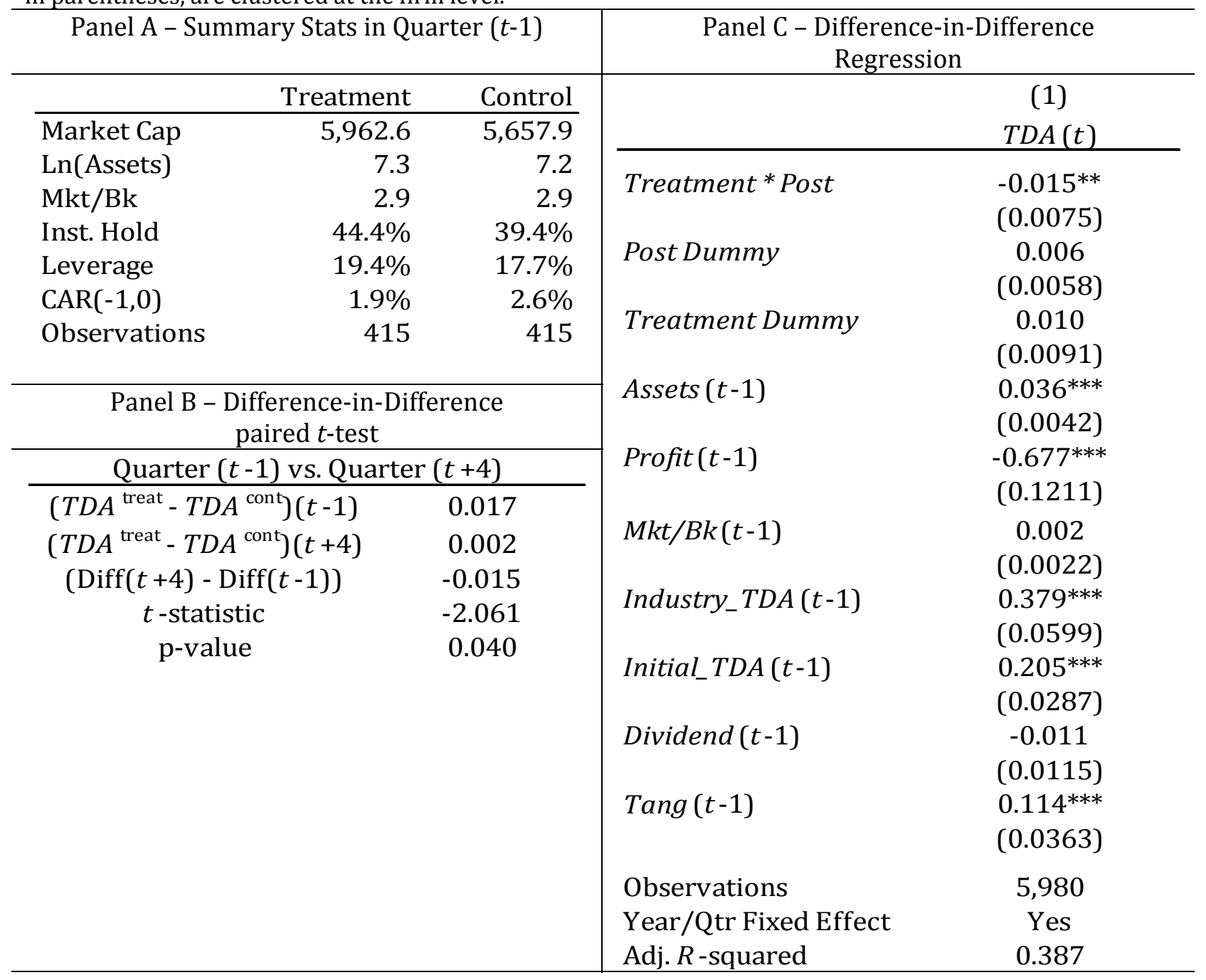




\section{Table VIII}

\section{The Effect of Institutional Holdings on Leverage - Tests of Underlying Frictions}

This table reports estimates from panel regressions of leverage on institutional holdings. The dependent variable, TDA, is measured at the end of fiscal year $t$, and the independent variables, described in Table I and defined in the Appendix, are measured as of time ( $t-1)$. In Panel A, we test whether agency costs or asymmetric information is behind the relationship between institutional holdings and leverage. Asymmetric Information (Agency) firms are small (large) firms with many (few) growth opportunities. Columns 1 and 2 contain the following independent variables, omitted for brevity: Intang, Payout, Unique, Losses, and ChgAssets. The data consist of all U.S. incorporated firms with CRSP, Compustat, and institutional holdings data between 1979 and 2009, excluding financial firms and utilities, with the additional requirement in columns 3 and 4 of at least four consecutive years of non-missing data. In Panel B, we use data between 2000 and 2006, excluding 2003, to test the impact of institutional holdings on leverage conditional on the size of the tax advantage enjoyed by institutions over individuals. The new variables Hold_00-02 and Hold_04-06 reflect this. The F test tests the equality of Hold_00-02 and Hold_04-06, with the null hypothesis being that they are equal. The following independent variables are included but omitted for brevity: Intang, Payout, Unique, Losses, and ChgAssets. Institutional holdings data is obtained from Thomson-Reuters via $13 \mathrm{~F}$ SEC filings. ${ }^{* * *},{ }^{* *}$, and ${ }^{*}$ represent statistical significance at the $1 \%, 5 \%$, and $10 \%$ level, respectively, and standard errors, reported in parentheses, are clustered at the firm level.

Panel A - Asymmetric Information or Agency Panel B - Taxes

Leverage in levels (cols 1-2), and difference GMM (cols 3-4)

(1) (2) (3) (4)

Asym. Info.: Agency: Asym. Info.: Agency:

\begin{tabular}{|c|c|c|c|c|c|c|}
\hline & $T D A(t)$ & $T D A(t)$ & $T D A(t)$ & $T D A(t)$ & & $T D A(t)$ \\
\hline $\operatorname{Hold}(t-1)$ & $\begin{array}{c}-0.147^{* * *} \\
(0.0526)\end{array}$ & $\begin{array}{c}-0.050^{* * *} \\
(0.0158)\end{array}$ & $\begin{array}{c}-0.220^{* * *} \\
(0.0787)\end{array}$ & $\begin{array}{c}-0.026 \\
(0.0189)\end{array}$ & Hold_00-02 $(t-1)$ & $\begin{array}{c}-0.077^{* * *} \\
(0.0113)\end{array}$ \\
\hline$T D A(t-1)$ & & & $\begin{array}{l}0.592^{* * *} \\
(0.0372)\end{array}$ & $\begin{array}{l}0.639^{* * *} \\
(0.0310)\end{array}$ & Hold_04-06 $(t-1)$ & $\begin{array}{c}-0.086^{* * *} \\
(0.0121)\end{array}$ \\
\hline $\operatorname{Assets}(t-1)$ & $\begin{array}{c}0.022^{*} \\
(0.0119)\end{array}$ & $\begin{array}{c}0.037^{* * *} \\
(0.0076)\end{array}$ & $\begin{array}{l}0.033^{* * *} \\
(0.0058)\end{array}$ & $\begin{array}{c}0.005^{*} \\
(0.0029)\end{array}$ & $\operatorname{Assets}(t-1)$ & $\begin{array}{l}0.022^{* * *} \\
(0.0019)\end{array}$ \\
\hline $\operatorname{Profit}(t-1)$ & $\begin{array}{c}-0.089^{* * *} \\
(0.0190)\end{array}$ & $\begin{array}{c}-0.297^{* * *} \\
(0.0476)\end{array}$ & $\begin{array}{c}-0.058^{* * *} \\
(0.0087)\end{array}$ & $\begin{array}{c}-0.029 \\
(0.0222)\end{array}$ & $\operatorname{Profit}(t-1)$ & $\begin{array}{c}-0.150^{* * *} \\
(0.0164)\end{array}$ \\
\hline$M k t / B k(t-1)$ & $\begin{array}{c}0.003 \\
(0.0020)\end{array}$ & $\begin{array}{c}0.015^{*} \\
(0.0077)\end{array}$ & $\begin{array}{c}0.000 \\
(0.0011)\end{array}$ & $\begin{array}{c}-0.002 \\
(0.0023)\end{array}$ & $M k t / B k(t-1)$ & $\begin{array}{l}0.004^{* * *} \\
(0.0014)\end{array}$ \\
\hline Industry_TDA $(t-1)$ & $\begin{array}{c}0.333^{* *} \\
(0.1561)\end{array}$ & $\begin{array}{l}0.293^{* * *} \\
(0.0643)\end{array}$ & $\begin{array}{c}0.097 \\
(0.0693)\end{array}$ & $\begin{array}{c}0.062^{* *} \\
(0.0292)\end{array}$ & Industry_TDA $(t-1)$ & $\begin{array}{l}0.246^{* * *} \\
(0.0291)\end{array}$ \\
\hline Dividend $(t-1)$ & $\begin{array}{c}-0.029 \\
(0.0234)\end{array}$ & $\begin{array}{c}0.002 \\
(0.0076)\end{array}$ & $\begin{array}{c}-0.004 \\
(0.0101)\end{array}$ & $\begin{array}{l}0.010^{* * *} \\
(0.0040)\end{array}$ & Dividend $(t-1)$ & $\begin{array}{r}-0.048^{* * * *} \\
(0.0057)\end{array}$ \\
\hline Capex $(t-1)$ & $\begin{array}{c}0.030 \\
(0.0554)\end{array}$ & $\begin{array}{c}0.048 \\
(0.0394)\end{array}$ & $\begin{array}{c}0.055^{*} \\
(0.0335)\end{array}$ & $\begin{array}{c}0.146^{* * *} \\
(0.0230)\end{array}$ & $\operatorname{Capex}(t-1)$ & $\begin{array}{c}-0.190^{* * *} \\
(0.0456)\end{array}$ \\
\hline $\operatorname{Tang}(t-1)$ & $\begin{array}{c}0.130^{*} \\
(0.0664)\end{array}$ & $\begin{array}{c}0.092 \\
(0.0562)\end{array}$ & $\begin{array}{c}-0.007 \\
(0.0356)\end{array}$ & $\begin{array}{l}-0.049 * * \\
(0.0226)\end{array}$ & $\operatorname{Tang}(t-1)$ & $\begin{array}{l}0.171^{* * *} \\
(0.0213)\end{array}$ \\
\hline $\operatorname{Colltrl}(t-1)$ & $\begin{array}{l}0.129 * * * \\
(0.0486)\end{array}$ & $\begin{array}{c}0.038 \\
(0.0513)\end{array}$ & $\begin{array}{c}0.043 \\
(0.0275)\end{array}$ & $\begin{array}{c}0.040^{* *} \\
(0.0186)\end{array}$ & $\operatorname{Colltrl}(t-1)$ & $\begin{array}{l}0.139^{* * *} \\
(0.0174)\end{array}$ \\
\hline Observations & 10,120 & 11,206 & 9,814 & 12,368 & Observations & 17,312 \\
\hline Firm Fixed Effect & Yes & Yes & Yes & Yes & Firm Fixed Effect & No \\
\hline Year Fixed Effect & Yes & Yes & Yes & Yes & Year Fixed Effect & Yes \\
\hline Adj. $R$-squared & 0.598 & 0.737 & & & $\operatorname{Pr}>F$ & 0.401 \\
\hline Hansen $J$-statistic & & & 62.04 & 57.79 & Adj. $R$-squared & 0.331 \\
\hline Hansen p-value & & & 0.270 & 0.409 & & \\
\hline
\end{tabular}




\section{Table IX}

\section{The Effect of Changes in Institutional Holdings on Equity and Debt Issuances}

This table presents estimates from logit and linear regressions of equity issuances on lagged changes in institutional holdings. Equity Issue (Equity Repo) is a dummy = 1 if the change in split-adjusted shares outstanding normalized by total assets, \% Change Equity, $>1 \%(<-1 \%)$, and 0 otherwise. \% Change Debt is the change in debt normalized by total assets, while Net Debt Issue $=1$ if \% Change Debt - \% Change Equity > 0, and 0 otherwise. All specifications contain an intercept. The control variables, data sources, and sample are described in Tables I and IV. ${ }^{* * *}, * *$, and * represent statistical significance at the $1 \%, 5 \%$, and $10 \%$ level, respectively, and standard errors, reported in parentheses, are clustered at the firm level.

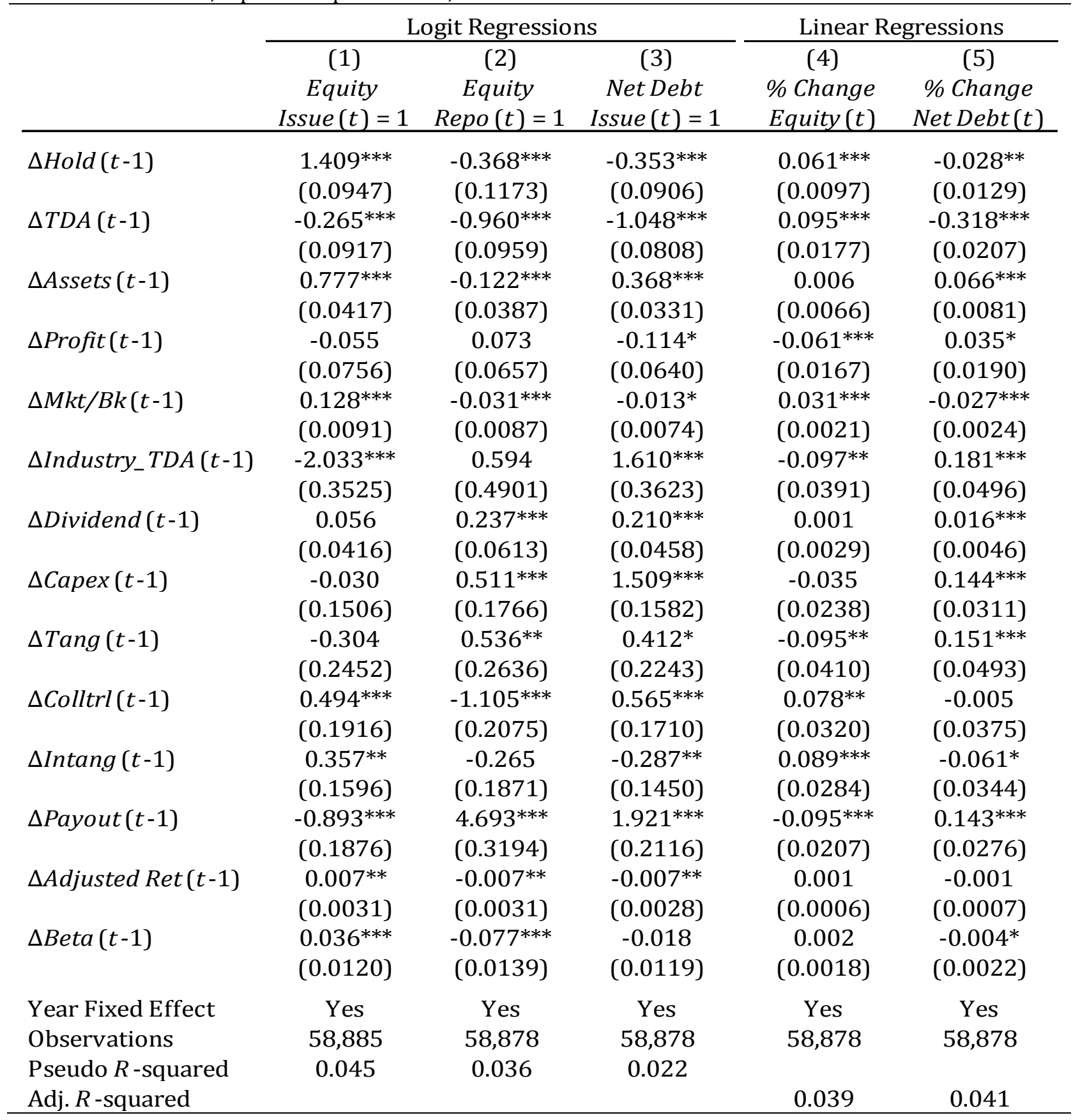

